Review

\title{
From lymphopoiesis to plasma cells differentiation, the age-related modifications of B cell compartment are influenced by "inflamm-ageing"
}

\author{
Matteo Bulati, Calogero Caruso*, Giuseppina Colonna-Romano \\ Immunosenescence Unit, Department of Pathobiology and Medical Biotechnologies (DIBIMED), University of Palermo, Italy
}

\section{A R T I C L E I N F O}

\section{Article history:}

Received 20 February 2017

Received in revised form 4 April 2017

Accepted 5 April 2017

Available online 7 April 2017

\section{Keywords:}

Age-related diseases

B cells

Exhausted/Senescent cells

Immunosenescence

Inflamm-ageing

\begin{abstract}
A B S T R A C T
Ageing is a complex process characterized by a general decline in physiological functions with increasing morbidity and mortality. The most important aspect of ageing is the chronic inflammatory status, named "inflamm-ageing", strictly associated with the deterioration of the immune function, termed "immunosenescence". Both are causes of increased susceptibility of elderly to infectious diseases, cancer, dementia, cardiovascular diseases and autoimmunity, and of a decreased response to vaccination. It has been widely demonstrated that ageing has a strong impact on the remodelling of the B cell branch of immune system. The first evident effect is the significant decrease in circulating B cells, primarily due to the reduction of new $B$ cell coming from bone marrow (BM) progenitors, as inflammation directly impacts on B lymphopoiesis. Besides, in aged individuals, there is a shift from naïve to memory immunoglobulins production, accompanied by the impaired ability to produce high affinity protective antibodies against newly encountered antigens. This is accompanied by the increase of expanded clones of B cells, which correlates with poor health status. Age-related modifications also occur in naïve/memory B cells subsets. Indeed, in the elderly, there is a reduction of naïve B cells, accompanied by the expansion of memory B cells that show a senescence-associated phenotype. Finally, elderly show the impaired ability of memory $\mathrm{B}$ cells to differentiate into plasma cells. It can be concluded that inflammation is the leading cause of the age-related impairment of B cell compartment, which play certainly a key role in the development of age-related diseases. This makes study of B cells in the aged an important tool for monitoring immunosenescence, chronic inflammatory disorders and the effectiveness of vaccines or pharmacological therapies.
\end{abstract}

(c) 2017 Elsevier B.V. All rights reserved.

\section{Contents}

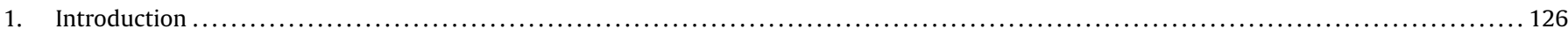

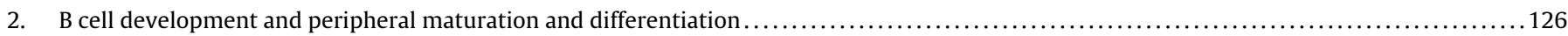

3. The reduced ability of elderly people to respond to newly encountered antigens and vaccinations reflects

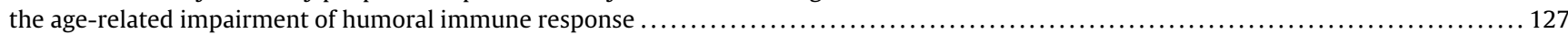

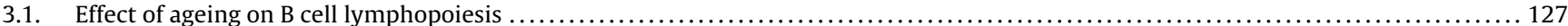

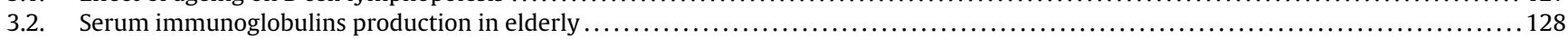

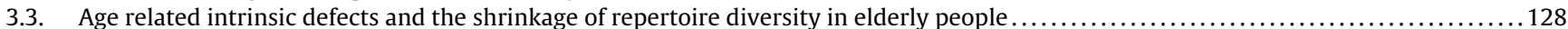

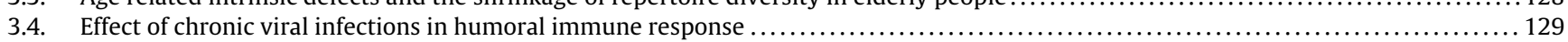

3.5. The age-related impairment of $B$ cell functions is associated with low responsiveness to influenza vaccination......................129

4. Age-related remodeling of $B$ cell subpopulations and the appearance of senescent/exhausted $B$ cells involved in inflamm-ageing ................130

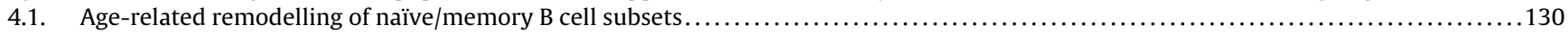

\footnotetext{
* Corresponding author.

E-mail address: calogero.caruso@unipa.it (C. Caruso).
} 
4.2. DN B lymphocytes are exhausted/senescent cells involved in inflamm-ageing, but, in some circumstances, might be 'active' ............131

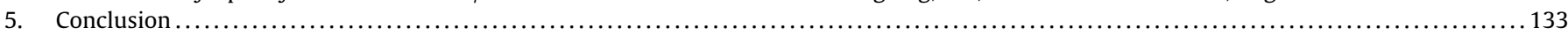

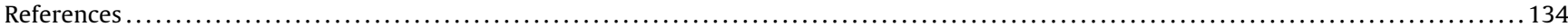

\section{Introduction}

In modern society, the increase of life expectancy of global population, coupled to a decline in birth rates in all developed countries, has lead to an extraordinary demographic revolution characterized by an explosive growth in the number and proportion of elderly people. Indeed, it has been estimated the doubling of the number of people over sixty years in 2050, and the octogenarians are expected to increase from 125 million in 2015-434 million in 2050 (United Nations: World Population Prospects; http://esa.un.org/unpd/wpp/ ). This long human life span underscores the importance of studies on ageing, longevity and health status in the ageing population, as these strongly influence the Government's economic strategies because of the increase of the subjects, which are not autonomous and are affected by invalidating pathologies (Christensen et al., 2008).

Ageing is a complex process characterized by a general decline in physiological functions with an increasing morbidity and mortality (Avery et al., 2014). The goal of ageing research is to identify the processes involved in loss of physiological functions, which lead older individuals to develop multiple pathologies, with the aim of developing effective strategies of interventions. On this regard, many experimental evidences, from a wide variety of organisms, suggest some evolutionarily conserved hallmarks of ageing, as altered intercellular communication, genomic instability, epigenetic alterations, telomere attrition, impaired protein homeostasis, altered nutrient and growth factor responsiveness, mitochondrial dysfunction, stem cell exhaustion and cellular senescence (López-Otín et al., 2013).

However, there is a common consensus in the scientific community that attributes the cause and the consequence of many aspects of ageing to the increased inflammatory status in elderly. It is well known that in aged people, the levels of inflammatory mediators increase even in the absence of acute infections or other stressors (Singh and Newman, 2011). This condition, characterized by a general increase in plasma levels of pro-inflammatory mediators (Bruunsgaard, 2006; Krabbe et al., 2004; Puzianowska-Kuźnicka et al., 2016), leads to a chronic, low-grade, pro-inflammatory status known as "Inflamm-ageing" (Cevenini et al., 2010; Salvioli et al., 2013; Vasto et al., 2007). The origin of inflamm-ageing is not still completely understood, several concurrent contributing factors have been suggested, such as age-related remodelling of innate and acquired immune system cells and molecules, chronic antigenic stimulation, including latent virus infection, the increase in the amount of self-debris, due to the continuous turnover of cells and tissues, such as circulating mitochondrial DNA and modified macromolecules (DNA or proteins modified by oxidation, acylation or glycosylation) and the presence of senescent cells exhibiting a senescence-associated secretory phenotype, as well as age-related changes in microbiota (Franceschi and Campisi, 2014; Fulop et al., 2016; Magrone and Jirillo, 2013).

Inflamm-ageing is, therefore, directly linked to the immune system (Salvioli et al., 2013). Indeed, it has been widely demonstrated a strong association between changes in immune functions and longevity, that indicates as the deterioration of the immune function, termed "immunosenescence", could be the cause of the increased susceptibility to infectious diseases, cancer, dementia, cardiovascular diseases and autoimmunity, and a decrease response to vaccination which characterize elderly people (Bucci et al., 2014; Fulop et al., 2016; Grasse et al., 2016; Salvioli et al.,
2013). The age-associated deregulation of the immune system is due to changes in both innate and acquired immunity, strictly associated with a systemic chronic inflammation (Salvioli et al., 2013), as demonstrated in several longitudinal studies in which it was examined the relationship occurring between immune parameters and survival of very old subjects (Wikby et al., 2005). The Swedish longitudinal OCTO and NONA studies have shown the immune characteristics associated with mortality in advanced age, defined "Immune Risk Phenotype" (IRP), that involves the main lymphocyte subsets such as, high $\mathrm{CD}^{+} \mathrm{T}$ cells percentage, low $\mathrm{CD}^{+} \mathrm{T}$ helper and $\mathrm{CD} 19^{+} \mathrm{B}$ cells percentages, the inverted CD4/CD8 ratio, impaired T cell proliferative responses and cytomegalovirus (CMV)seropositivity (Strindhall et al., 2007; Wikby et al., 2005).

It has been well established that $\mathrm{T}$ cell compartment of elderly shows shrinkage of cellular repertoire and filling of the immunological space by a population of late-differentiated cytotoxic $\mathrm{T}$ cells, caused by the chronic antigenic load (Derhovanessian et al., 2010, 2013). The direct consequence of these changes, together with the reduced output of naïve $T$ cells from the thymus, is the reduction of antigen-inexperienced $\mathrm{T}$ lymphocytes available for adequate immune response against newly encountered antigens (Aberle et al., 2013; Pawelec 2014a,b).

$B$ cell branch of immune system also behaves as $T$ cell compartment, with a shift in the magnitude of all B cell populations, a collapse in $B$ cell receptor repertoire diversity, correlated with a poor health status, a modified peripheral B cell dynamics, and a weakened humoral response due to the impairment of antibodies production (Aberle et al., 2013; Bulati et al., 2011; Cancro et al., 2009; Dunn-Walters and Ademokun 2010; Frasca and Blomberg, 2016; Gibson et al., 2009; Naradikian et al., 2016).

From these considerations, it could be stated that ageing has a strong impact on the remodelling of the acquired immune system cells and that there is an age-related accumulation of immune cells with "exhausted/senescent" phenotype with altered functions, at the expense of naïve antigen-inexperienced cells (Bulati et al., 2011, 2014; Fulop et al., 2016; Larbi and Fulop, 2014; Naradikian et al., 2016; Pawelec, 2014a,b; Pinti et al., 2016; Rubtsova et al., 2015).

In this paper, we review data from literature on the age-related changes at systemic, molecular and cellular levels of B cells compartment, focusing on the important role played by B lymphocytes impairment as cause/effect of inflamm-ageing.

\section{B cell development and peripheral maturation and differentiation}

B cells originate in the bone marrow (BM) from hematopoietic stem cells (HSC) committed for specific B cell lineage. Pro- and preB cell precursor express two specific surface markers, CD10 and interleukin(IL)-7 receptor $\alpha$. In the presence of IL-17, produced into the BM, B cells rearrange the variable (V), diversity (D) and joining (J) regions of the immunoglobulin $(\mathrm{Ig})$ heavy $(\mathrm{H})$ chain genes in a stage defined pro- $B$ cell. In this process are involved the products of RAG-1 and RAG-2 genes. Successful rearrangement initiates pre$B$ cell stage, where cells first express a pre-B cell receptor (BCR), together with two trans-membrane signaling molecules (Ig $\alpha$ and $\operatorname{Ig} \beta$ ), then rearrange the Ig light chain gene ( $\mathrm{V}$ and $\mathrm{J}$ gene) of the immunoglobulin. After that Ig genes rearrangement is complete, RAGs gene expression is down-regulated and $\mathrm{CD} 10^{+}$immature $\mathrm{B}$ cells in the BM lose the expression of IL-7R $\alpha$, express CD5 and start 
Table 1

Cellular age-related modification of B cell compartment.

\begin{tabular}{|c|c|c|c|c|}
\hline & Name/Type & Location & $\begin{array}{l}\text { Effect of } \\
\text { ageing }\end{array}$ & References \\
\hline \multirow[t]{2}{*}{ Precursors } & HSC & BM & Reduced & $\begin{array}{l}\text { Pang et al. (2011), Rossi et al. } \\
\text { (2005) }\end{array}$ \\
\hline & B lymphopoiesis & BM & Reduced & $\begin{array}{l}\text { Riley et al. (2013), Henry et al. } \\
\text { (2015) }\end{array}$ \\
\hline \multirow[t]{12}{*}{$\begin{array}{l}\text { Mature B cells and } \\
\text { Plasma Cells }\end{array}$} & CD19 ${ }^{+}$Total B cells & Periphery & Reduced & $\begin{array}{l}\text { Bulati et al. (2011), } \\
\text { Colonna-Romano et al. (2009), } \\
\text { (2000), Lin et al., (2016), Pinti et al., } \\
\text { (2016), Strindhall et al. (2007) }\end{array}$ \\
\hline & Naïve [IgD ${ }^{\mathrm{High}} \operatorname{IgM}^{\mathrm{High}} \mathrm{CD} 27^{-}{ }^{-}$ & Periphery/LNs & Reduced & $\begin{array}{l}\text { Bulati et al. (2011), } \\
\text { Colonna-Romano et al. (2009), } \\
\text { Gupta et al. (2005) }\end{array}$ \\
\hline & & & Increased & Frasca et al. (2008) \\
\hline & Memory Unswitched [IgD $\left.{ }^{\mathrm{High}} \operatorname{IgM}^{\mathrm{High}} \mathrm{CD} 27^{+}\right]$ & Periphery/LNs & No Change & $\begin{array}{l}\text { Bulati et al. (2011), } \\
\text { Colonna-Romano et al. (2009) }\end{array}$ \\
\hline & $\begin{array}{l}\text { Memory switched }\left[\operatorname{IgD}^{-} \text {(Switched Igs, }\right. \\
\left.\left.\operatorname{IgG}^{+} / \operatorname{igA}^{+} / \operatorname{IgE}^{+}\right) C D 27^{+}\right]\end{array}$ & Periphery/LNs & No Change & $\begin{array}{l}\text { Bulati et al. (2011), } \\
\text { Colonna-Romano et al. (2009) }\end{array}$ \\
\hline & & & Reduced & Frasca et al. $(2008,2012 b)$ \\
\hline & IgM-only memory $\left[\operatorname{IgD}^{-} \operatorname{IgM}{ }^{+} \mathrm{CD} 27^{+}\right]$ & Periphery/LNs/Spleen & Reduced & Buffa et al. (2011), Shi et al. (2005) \\
\hline & $\begin{array}{l}\text { Double Negative (DN) }\left[\operatorname{IgD}^{-} \text {(Switched Igs, }\right. \\
\left.\left.\operatorname{IgG}^{+} / \mathrm{igA}^{+} / \operatorname{IgE}^{+}\right) \mathrm{CD}^{-} 7^{-}\right]\end{array}$ & $\begin{array}{l}\text { Periphery/LNs/Inflamed } \\
\text { Tissues }\end{array}$ & Increased & $\begin{array}{l}\text { Bulati et al. (2011), } \\
\text { Colonna-Romano et al. (2009), } \\
\text { Frasca et al. (2011) }\end{array}$ \\
\hline & $\mathrm{CD} 24^{-} \mathrm{CD}^{-} 8^{-} \mathrm{B}$ cells & Periphery/LNs & Increased & $\begin{array}{l}\text { Buffa et al. (2013), Palma et al. } \\
\text { (2014) }\end{array}$ \\
\hline & $\begin{array}{l}\text { Age-associated B cells (ABC) } \\
{\left[\mathrm{CD} 19^{+} \mathrm{CD} 11 \mathrm{~b}^{+} \mathrm{CD} 11 \mathrm{c}^{+} \mathrm{CD} 21^{-} \mathrm{IgD}^{-}\right]}\end{array}$ & Periphery/LNs & Increased & $\begin{array}{l}\text { Naradikian et al. (2016), Rubtsova } \\
\text { et al. (2015) }\end{array}$ \\
\hline & TNF- $\alpha$-producing B cells & Periphery/LNs & Increased & Frasca et al. (2014) \\
\hline & Plasma Cells & Periphery/BM & Reduced & Pritz et al. (2015) \\
\hline
\end{tabular}

to express IgM as part of a not yet functional BCR (Sagaert and De Wolf-Peeters, 2003).

The most part of immature B cells leave BM and complete their differentiation in the periphery in a series of stages that lead to the formation of transitional B cells. These cells continue to express CD10, co-express IgD and IgM and present high expression of CD24 and CD38 (Carsetti et al., 2004). A little percentage of these $\mathrm{CD} 24^{\text {high }} \mathrm{CD} 38^{\text {high }}$ transitional $\mathrm{B}$ cells are founded in peripheral blood and are able to produce IL-10, behaving as B regulatory cells (Blair et al., 2010; Carsetti et al., 2004). The fate of these cells depends on BCR signalling strength (Pillai and Cariappa, 2009). Indeed, some of them join the marginal zone of the spleen, where they differentiate into $\mathrm{CD} 27^{+} \operatorname{IgM}{ }^{+}$B cells, which have the role to provide a first line defence against encapsulated bacteria (Shi et al., 2005). While, the large majority of transitional B cells become mature follicular B cells, which include precursors of naïve and memory B cells, and represent about $80-90 \%$ of total B lymphocytes. Mature B cell survival and peripheral activation is influenced by B-cell maturation protein (BCMA), a member of the tumor necrosis factor (TNF) receptor family that is expressed in B lymphocytes. BCMA binds two proteins belonging to TNF family, B cell activating factor (BAFF) and a proliferation-inducing ligand (APRIL), produced by monocytes, macrophages and dendritic cells, that stimulate cellular proliferation and survival (Reber et al., 2012). Mature B cells, can be found in the periphery as well as in secondary lymphoid organs, lose the expression of CD10, become able to recognize antigens and express different surface markers. In particular it is possible to identify circulating naïve and memory B cells on the basis of the differential expression of IgD and CD27 surface markers as follows: $\operatorname{IgD}^{+} \mathrm{CD} 27^{-}$naïve $\mathrm{B}$ cells, $\operatorname{IgD}^{+} \mathrm{CD} 27^{+}$ memory unswitched B cells, $\operatorname{IgD}^{-} \mathrm{CD} 27^{+}$memory switched B cells and $\mathrm{IgD}^{-} \mathrm{CD}^{-} 7^{-}$double negative (DN) memory B cells (Buffa et al., 2013; Bulati et al., 2011, 2014; Colonna-Romano et al., 2009; Frasca et al., 2011; Kaminski et al., 2012; Shi et al., 2005). Moreover, mature B cells are able to recirculate from periphery to lymphoid organs or other tissues, due to the expression of different combination of chemokine receptors on their surface (Perez-Andres et al., 2010; Stein and Nombela-Arrieta, 2005).

The ability of mature B cells to undergo germinal centre (GC) reaction, producing highly specific Igs, depends on immunoglobulin affinity maturation, a process governed by both cytokines production in GCs and by the T-B cells cognate interaction, through the triggering of CD40, on activated B cells, with CD154 (or CD40 Ligand), expressed on the T cell membrane. Ligation of cytokines, as IL-4, IL-10, IL-21, with their receptors on B cells, causes the activation of STAT6, NF-kB and of activation-induced deaminase (AID) transcription factors (Stavnezer et al., 2008). The action of AID, that introduces double strand breaks in the Ig germline, leads to the introduction of point mutations in the $\mathrm{V}$ region of memory $\mathrm{B}$ cells, called somatic hyper-mutations (SHMs), that modulate the antibody-antigen $(\mathrm{Ab}-\mathrm{Ag})$ affinity, while in the $\mathrm{C}$ region of naïve B cells, AID action, leads to class switch recombination (CSR), that allows the transcription of the selected $\mathrm{V}$ region in association with IgG, IgA, or IgE, having better effector functions than IgM.

Finally, serological memory is maintained by long lived plasma cells, that recirculate between the periphery and the BM, and by memory B cells being continuously re-stimulated by bystander cytokines producing-T cells as well as by microbial products triggering Toll-like Receptors (TLRs) expressed on B cells, even in the absence of specific antigens (Bernasconi et al., 2002).

\section{The reduced ability of elderly people to respond to newly encountered antigens and vaccinations reflects the age-related impairment of humoral immune response}

\subsection{Effect of ageing on B cell lymphopoiesis}

As discussed, the ageing process is associated with functional impairment at the tissue, cellular and molecular levels (López-Otín et al., 2013). These age-associated changes are particularly evident in the BM. Indeed, in the elderly, it has been shown a reduction in the BM density and changes in the vascularization and in the com- 
Table 2

Serological and molecular age-related modification of B cell compartment.

\begin{tabular}{|c|c|c|c|}
\hline Molecules & Age-related modification & Effect of modification & References \\
\hline IL-7-enriched niches in the BM & Reduced & Impaired B lymphopoiesis & $\begin{array}{l}\text { Henry et al. (2015), Ueda et al. } \\
\text { (2004) }\end{array}$ \\
\hline BAFF plasma levels & Reduced & Impaired survival and maturation of peripheral B cells & Jin et al. (2008) \\
\hline APRIL plasma levels & Reduced & & Jin et al. (2008) \\
\hline Total Serum Igs & No Change & Impaired ability to respond to new antigenic challenge & Aberle et al. (2013), Listi et al. \\
\hline Serum IgD/IgM & Reduced & & (2006), Naradikian et al. (2016), \\
\hline Serum IgG/IgA & Increased & & Weksler and Szabo (2000) \\
\hline B cell receptor repertoire & Reduced & $\begin{array}{l}\text { Impaired response against foreign antigens, expansion of } \\
\text { oligoclonal populations, reduced diversity of BCR } \\
\text { repertoire, reduced antibody specificity and affinity, } \\
\text { increased reactivity against autologous molecules }\end{array}$ & $\begin{array}{l}\text { Dunn-Walters, (2016), Gibson } \\
\text { et al. (2009), Weksler and } \\
\text { Szabo (2000) }\end{array}$ \\
\hline E47 expression & Reduced & $\begin{array}{l}\text { Reduced ability to generate higher affinity protective } \\
\text { antibodies }\end{array}$ & $\begin{array}{l}\text { Frasca et al. }(2013,2014, \\
2015 a, b)\end{array}$ \\
\hline AID expression & Reduced & & \\
\hline miR-155 expression & Increased & Induce AID mRNA degradation & Frasca et al. (2016) \\
\hline miR-16 expression & Increased & Induce E47 mRNA degradation & \\
\hline BTLA expression & Reduced & $\begin{array}{l}\text { Decreased induction of long-lived plasma cells, memory B } \\
\text { cells and antibody titres }\end{array}$ & Kannan et al. (2015) \\
\hline Blimp-1 Expression & Reduced & Impaired ability of B cells to differentiate into plasma cells & Frasca et al. (2016) \\
\hline
\end{tabular}

position of the resident cells (Chan and Duque, 2002). It has been widely demonstrated that the function of HSC significantly declines with age (Pang et al., 2011; Rossi et al., 2005). Hematopoietic defects are particularly evident in the lymphoid lineages, and can be attributed to the skewing of the HSC repertoire toward myeloid lineages (Beerman et al., 2010; Guerrettaz et al., 2008). Moreover, the aged BM microenvironment has been suggested to contribute to the reduction of B lymphopoiesis (Riley, 2013). Recently, it has been demonstrated that TNF- $\alpha$ and high concentration of transforming growth factor (TGF)- $\beta$, suppress HSC activity (Challen et al., 2010; Pronk et al., 2011), while IFN- $\alpha$, IFN- $\gamma$ and low concentration of TGF- $\beta$, activate HSC proliferation (Baldridge et al., 2010; Essers et al., 2009). In addition, inflammation has been shown to directly impair B lymphopoiesis (Table 1 ) by preventing B progenitors localization to the IL-7-enriched niches required for B cell development (Henry et al., 2015; Ueda et al., 2004). So, given the strong correlation between advanced age and chronic systemic inflammation previously stated, inflamm-ageing has an important impact on B cell progenitors population in elderly, not only reducing the output of new B cells, but also influencing the evolution of leukaemia, typical cancer of elderly people (Henry et al., 2015). Indeed, preventing the age-associated reduction of $\mathrm{B}$ cell progenitors, by using transgenic expression of two different anti-inflammatory proteins, as $\alpha$-1-antitrypsin and IL-37, in old mice, it has been demonstrated that selection for oncogene-initiated progenitors were abrogated (Henry et al., 2015).

\subsection{Serum immunoglobulins production in elderly}

The effect of ageing on $B$ cell compartment is a dramatic decrease in circulating B lymphocytes (Table 1 ), also observed in very old and centenarian subjects (Bulati et al., 2011; Colonna-Romano et al., 2009; Globerson and Effros, 2000; Lin et al., 2016; Pinti et al., 2016; Strindhall et al., 2007). As previously stated, reduced numbers and percentages of $\mathrm{CD} 19^{+} \mathrm{B}$ cells are part of the cluster of immune parameters, collectively known as "IRP", associated with 2-, 4-, and 6 -year mortality of the very elderly in the Swedish OCTO/NONA longitudinal studies (Strindhall et al., 2007; Wikby et al., 2005). This dramatic age-related reduction of mature B cells is influenced, not only by the reduced output of new B cells, but also by changes in the microenvironment that supports the survival of mature B cells in the periphery. The two TNF ligand superfamily proteins, BAFF and APRIL, are critical survival factors for peripheral mature B cells and it has been demonstrated that, in elderly people, the blood plasma level of these factors is reduced (Table 2) (Jin et al., 2008).
Furthermore, total serum immunoglobulin levels do not change with age (Aberle et al., 2013; Naradikianet al., 2016; Weksler and Szabo, 2000). Switched immunoglobulins (IgG and IgA) levels are positively age-related, whereas a reduced ability of the elderly and centenarians to produce IgD and IgM is reported (Listì et al., 2006). These Igs are together expressed on mature B cells newly produced by the bone marrow, hence suggesting that in the elderly and in centenarians, the B cell repertoire available to respond to new antigenic challenge is impaired (Table 2). Moreover, functional studies reported the impaired ability of memory B cells to produce Igs, after in vitro stimulation, and the reduction of plasma cell differentiation in elderly people (Naradikian et al., 2016; Pritz et al., 2015; Shi et al., 2005). These results are in agreement with the reduction of clonotypic response to newly encountered antigens in the elderly, together with an increased expansion of monoclonal B cells, that always lead to lymphoid malignancy that emerge with a relative frequency in advanced age (Henry et al., 2015).

\subsection{Age related intrinsic defects and the shrinkage of repertoire diversity in elderly people}

As above discussed, in aged individuals there is a shift from IgM, mainly produced by naïve B cells, to IgG or IgA, produced by memory cells, production (Listi et al., 2006), accompanied by an impaired ability to produce high affinity protective antibodies against infectious agents. This feature is due to both extrinsic, or intrinsic defects, as impaired T-B cell signalling (Haynes et al., 2003; Pinti et al., 2016), or decreased SHM and CSR in germinal center B cells (Frasca and Blomberg, 2016; Zheng et al., 1997), respectively, which cause a reduced production of switched and high affinity Igs.

In particular, it has been demonstrated a pivotal role of the age-related intrinsic defects as the cause of the impaired ability of elderly people to respond to new infections or vaccines (Frasca et al., 2013, 2014, 2015a,b). These defects include the decreased expression and production of the E47 transcription factor, which controls the expression of AID, the enzyme of CSR and SHM, which, in turn, results reduced (Table 2). As AID is considered a measure of optimal B cell responses, its decreased expression on B cells from elderly individuals, explains, in part, their reduced ability to generate higher affinity protective antibodies (Frasca and Blomberg, 2014, 2016; Khurana et al., 2012). In addition, it has been also shown an age-related reduction of E47 and AID mRNAs expressions, caused by the reduced mRNA stability. This phenomenon is strictly related to inflamm-ageing (Frasca and Blomberg, 2008), indeed, in the elderly, it has been observed the increased expression of the 
two pro-inflammatory micro-RNAs (miRNAs) (Table 2), miR-155 and miR-16, that respectively bind the $3^{\prime}$-untraslated region (UTR) of AID mRNA and the 3'-UTR of E47 mRNA, inducing their degradation (Frasca et al., 2015a). The increase of these two miRNAs in the elderly is also related to the stage of differentiation of B cells. Indeed, it has been recently observed that only memory B cells and, in particular, DN B cells, express high levels of these two molecules (Frasca et al., 2017).

Mi-RNAs are a class of molecule involved in gene expression regulation. Many studies have been demonstrated that they act as modulators of some pathways (NF-kB, mTOR, TGF- $\beta$ ) related to inflammation, cellular senescence and age-related diseases, including cancer (Reviewed by Oliveri et al., 2013)

Concerning miR-155, it has been shown that it is an oncomicroRNA involved in tumor initiation and development of several B cell malignancies, typical of elderly (Lawrie, 2013). It has been recently shown that miR-155 was up-regulated in several malignancies, as diffuse large B cell lymphoma and chronic lymphocytic leukaemia, and its over-expression is also associated with poor prognosis, rendering miR-155 a good diagnostic and prognostic biomarker in B cell cancer (Due et al., 2016). Moreover, both miR155 and miR-16, were demonstrated to be over-expressed, at the systemic level, during the natural course of Rheumatoid Arthritis (Churov et al., 2015), demonstrating the pro-inflammatory role of these two molecules.

At molecular level, the specificity of a single B cell is dependent on the variable region of Ig genes. For this reason the study of Ig genes can determine the extent of the repertoire in terms of BCR specificity. Age-related changes in the B cell repertoire (Table 2) involve impaired response against foreign antigens, expansion of oligoclonal populations, reduced diversity of the B cell repertoire, the increase of the reactivity against autologous molecules and, probably, reduced antibody specificity and affinity (Dunn-Walters, 2016; Gibson et al., 2009; Weksler and Szabo, 2000). Reduced B cell diversity could be due to both the impaired B cell lymphopoiesis in the BM and to the reduced diversification in the GC (Weksler and Szabo, 2000). The diversity of the B cell repertoire can be measured using spectratype analysis of the 3rd complementarydetermining region (CDR3) of the immunoglobulin (Dunn-Walters, 2016; Gibson et al., 2009). The diversity of the Ig heavy chain (IgH) CDR3 region is due to the addiction and/or deletion of nucleotides during V, D and J genes rearrangement (VanDyk and Meek, 1992). In healthy young people, the mRNA CDR3 size diversity, in spectratype analysis, is represented by a bell-shaped profile of peaks. While, elderly people show a distorted profile in their CDR3 spectratype from the normal distribution, indicating a collapse in B cell diversity and an oligoclonal expansion in the B cell repertoire which correlate with poor health survival in the very elderly (Gibson et al., 2009).

The advent of high-throughput sequencing has enabled a more detailed and comprehensive study of changes in the Ig gene repertoire. Indeed, it has been shown that older people have switched memory cells with a higher load of mutation also before vaccination; this observation confirms in detail that some people have pre-expanded repertoire of B cells (Ademokun et al., 2011; DunnWalters, 2016), which ultimately leads to a less efficient response to new encounter antigens or vaccines (Jiang et al., 2013).

So, the reduced antibody specificity and affinity may be true for some very specific case, but whether such change are directly caused by advanced age requires more studies on BCR sequencing and a better knowledge of their functions at the repertoire level. The age-related reduced AID activity and the oligoclonal expansion of the $B$ cell repertoire, alone, are not enough to explain the altered Igs production and the impaired ability to respond to new antigens of elderly people. To confirm whether these features have an important role in the quality and quantity changes of immunoglobulin, longitudinal analysis, in combination with deep sequencing of Igs, are indispensable.

\subsection{Effect of chronic viral infections in humoral immune response}

An important role in the ageing of B cell compartment, as well as in the age-related $\mathrm{T}$ cell impairment (Oxford et al., 2015; Pawelec et al., 2014a,b), is played by chronic viral infections such as CMV and Epstein-Barr virus (EBV). These two herpes viruses have a selective effect on the B cell repertoire, affecting the clonal expansion (EBV) or the levels of mutation of antibodies (CMV) (Wang et al., 2014). The consequence is that, with ageing, the CMV- or EBV-seropositivity and/or their reactivation, result to be a selective pressure, for the impairment of the humoral arm of the immune system in people of advanced age (Dunn-Walters, 2016). At this regard, it has been recently demonstrated (Pritz et al., 2015) that the frequency of plasma cell decreases with age, except for influenza A- and CMV-specific plasma cells, that are not affected by age. Moreover, with the exception of CMV, peripheral antibodies concentration is correlated with BM plasma cells of the same specificity, but is independent on antigen-specific memory B cells in the periphery. These results demonstrate that the frequency of specific plasma cells may reflect the number and time point of previous antigen encounters together with the intrinsic age-related changes in the BM (Pritz et al., 2015).

Inflamm-ageing and, in particular, CMV-seropositivity, is also the cause of the age-related increase of $\mathrm{B}$ cells that spontaneously produce higher amounts of TNF- $\alpha$ (Table 1 ). These TNF- $\alpha$-expressing B cells are positively correlated with serum TNF- $\alpha$ and negatively correlated with the ability of B cells to respond to in vitro stimulation, measured by AID (Frasca et al., 2012a, 2014). Additionally, high serum TNF- $\alpha$ levels and increased TNF- $\alpha$-producing B cell, are also negatively correlated with the in vivo serum response to the influenza vaccine (Frasca et al., 2014), suggesting that TNF- $\alpha$, in addition to micro-RNAs (miR-155 and miR-16), is a marker of intrinsic B cell inflammation, which contributes to the down-regulation of AID in B cells from aged individuals. The higher levels of both serum TNF- $\alpha$ and of TNF$\alpha$-producing B cells in the elderly are strictly associated with the age-related increase of CMV seropositivity (Pinti et al., 2016), which has been shown to have a negative effect on influenza vaccinespecific antibody responses (Frasca et al., 2015b).

\subsection{The age-related impairment of B cell functions is associated with low responsiveness to influenza vaccination}

Even though the vaccine efficacy tends to be less than optimal, influenza vaccination continues to be highly recommended in the elderly, as influenza is strictly associated with morbidity and mortality in very old people, because of the complications due to the infection as primary influenza pneumonia or secondary bacterial infections, together to the exacerbations of pre-existing medical conditions (Frasca and Blomberg, 2014). The immune response to influenza virus antigens is unique in humans, as they are repeatedly exposed to the virus, through natural infection or vaccination. In adults, influenza vaccine elicits both recall responses to epitopes that are shared with previously encountered viruses and primary responses to new antigenic epitopes (Kannan et al., 2015). For these reasons, recall responses are expected to be particularly predominant in the elderly due to their several exposures to influenza viruses or vaccines, but, as previously discussed, there is an age-related decrease of the influenza vaccine-specific antibody response. In a recent paper (Kannan et al., 2015), it has been demonstrated that B cells from elderly show a significant reduced expression of the co-inhibitor $B$ and $T$ lymphocyte attenuator (BTLA) prior to vaccination compared to young subjects. The 
authors demonstrated that BTLA expression on mature B cells is linked to the increase of H1N1-specific IgG antibody titres and is involved in the shifting of the response from IgM to IgG. So, the decline of BTLA expression on B cells (Table 2), may be related to decreased induction of long-lived plasma cells, memory B cells and antibody titres in aged people (Kannan et al., 2015).

Moreover, in a recent paper (Frasca et al., 2016), it has been demonstrated that, with ageing, the in vivo antibody response to the new influenza vaccine, the in vitro B cell activation and the expression of the transcription factor E47, are significantly decreased. But, surprisingly, memory B cells are maintained, and this is probably due to their amplification in response to repeated vaccinations. Indeed, the authors have shown that, nevertheless the serum Igs titres after vaccination were lower in the elderly, the frequencies of influenza vaccine-specific memory B cells and plasma blasts were not dissimilar between young and elderly individuals. Moreover, they have shown an age-related reduction of the transcription factor Blimp-1 (Table 2), which regulates plasma cells differentiation, suggesting that, even if the frequency of memory B cells is maintained during ageing, they have an impaired ability to differentiate to plasma cells (Frasca et al., 2016). Finally, as discussed, chronic CMV infection, is able to down-regulate the antibody response to the influenza vaccine both directly, inducing TNF- $\alpha$ production by B cell, and indirectly through the induction of terminally differentiated $\mathrm{T}$ cells and accumulation of senescent $\mathrm{T}$ cells, which could lead to reduced generation of memory $\mathrm{T}$ cells (Derhovanessian et al., 2013; McElhaney et al., 2010).

\section{Age-related remodeling of $B$ cell subpopulations and the appearance of senescent/exhausted $B$ cells involved in inflamm-ageing}

\subsection{Age-related remodelling of naïve/memory B cell subsets}

The age-related impairment of antibodies production and the shrinkage of the repertoire diversity are obviously reflected in changes occurring in naïve/memory B cells subsets. This is an important feature, as it is known that B cells also have regulatory and effector functions, such as $\mathrm{T}$ cell and dendritic cell regulation, cytokine, chemokine and other effector molecules, as granzyme B, production (Bulati et al., 2014; Harris et al., 2000; Sanz et al., 2008), rendering these cells key mediators in the control of the immune response and/or in the generation or maintenance of inflammation (Klinker and Lundy, 2012; Lund, 2008; Lund and Randall, 2010; Rosser and Mauri, 2015; Vazquez et al., 2015).

As previously stated, the reduced number of circulating B lymphocytes is a typical feature of ageing (Strindhall et al., 2007), and changes in the relative frequencies of the different $B$ cell subsets have been reported (Bulati et al., 2011; Colonna-Romano et al., 2009; Frasca et al., 2011; Lin et al., 2016; Naradikian et al., 2016). The univocal evaluation of specific B cell subsets is complicated, both by variations between individuals (Lin et al., 2016), and by the use of different phenotype markers to characterize them, which are correlated with their functional/developmental stage, activation status, recirculation properties or anatomic location. So, different functional B cell subsets have been identified in humans using many cellular markers, and, among these IgD, CD27, CD24 and CD38, as well as surface Igs (IgM, IgG, IgA).

However, "core" subsets may be identified by evaluating only IgD and CD27 expression on CD19B cells (Kaminski et al., 2012). As above discussed, on the basis of the expression of these two markers, circulating $\mathrm{B}$ cells can be divided into different functional subsets: (1) $\operatorname{IgD}^{+} \mathrm{CD} 27^{-}$naïve $\mathrm{B}$ cells, (2) $\operatorname{IgD}^{+} \mathrm{CD} 27^{+}$memory unswitched B cells, (3) $\mathrm{IgD}^{-} \mathrm{CD} 27^{+}$memory switched $\left(\mathrm{IgG}^{+}\right.$or $\left.\operatorname{IgA}^{+}\right)$B cells and (4) IgD ${ }^{-} \mathrm{CD}^{-} 7^{-}$double negative memory switched
$\left(\operatorname{IgG}^{+}\right.$or $\left.\operatorname{Ig} \mathrm{A}^{+}\right)(\mathrm{DN}) \mathrm{B}$ cells, that as reviewed (Bulati et al., 2011), show characteristics of senescent/exhausted memory B cells. The unswitched cells also express IgM and have been designated as IgM memory B cells $\left(\operatorname{IgD}^{+} \operatorname{IgM}^{+} \mathrm{CD} 27^{+}\right)$, while some of the $\operatorname{IgD}{ }^{-} \mathrm{CD} 27^{+}$ (memory switched) are $\operatorname{IgM}^{+}$and have been designated as "IgMonly" memory B cells (Buffa et al., 2013; Bulati et al., 2011, 2014; Colonna-Romano et al., 2009; Frasca et al., 2011; Kaminski et al., 2012; Shi et al., 2005). On the basis of this kind of classification, it has been shown a significant age-related reduction of IgD ${ }^{+}$CD27- naïve B cells (Colonna-Romano et al., 2009; Gupta et al., 2005; Lin et al., 2016), no age-related changes in $\operatorname{IgD}^{+} \mathrm{CD} 27^{+}$memory unswitched and $\mathrm{IgD}^{-} \mathrm{CD} 27^{+}$memory switched B cells (Bulati et al., 2011; Colonna-Romano et al., 2009), while $\operatorname{IgD}^{-}$CD27- DN memory B cells are significantly increased in the elderly and in centenarians (Bulati et al., 2011; Colonna-Romano et al., 2009; Frasca et al., 2011). Other authors, instead, have described the increase of naïve B cells in the elderly (Frasca et al., 2008), but they considered

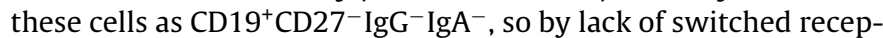
tor rather than by the presence of IgD. Moreover the same authors have described an age-related decrease of memory switched $B$ cells, identifying them as $\operatorname{IgG}^{+} / \operatorname{IgA}^{+} \mathrm{CD} 27^{+}$(Frasca et al., 2012b) (Table 1). For these reasons, a further characterization of naïve/memory $B$ cells, identified by IgD and CD27 markers, was carried out, and it revealed, in each of the four subpopulations, a particular surface Igs (IgM, IgG or IgA) expression. Briefly, it has been shown that both naïve $\left(\operatorname{IgD}^{+} \mathrm{CD} 27^{-}\right)$and memory unswitched $\left(\operatorname{IgD}^{+} \mathrm{CD} 27^{+}\right) \mathrm{B}$ cells, express only IgM, in both young and elderly subjects. Concerning DN $\left(\operatorname{IgD}^{-} \mathrm{CD} 27^{-}\right)$memory cells, most of them were $\operatorname{IgG}^{+}$ or $\operatorname{IgA}^{+}$(Table 3 ), and less than $10 \%$ were $\operatorname{IgM}^{+}$. Also in this case it was not found any age-related differences in the relative expression of IgM, IgG or IgA isotypes. In contrast, the proportion of IgG, IgA and IgM memory B cells in the switched memory compartment $\left(\operatorname{IgD}^{-} \mathrm{CD} 27^{+}\right)$resulted to be different between young and old, with a significant decrease of $\operatorname{IgM}^{+} \operatorname{IgD}^{-} \mathrm{CD} 27^{+}$memory B cells (Table 1 ) in the elderly (Buffa et al., 2011). This result is in agreement with previous data demonstrating a reduction of "IgM-only" memory B cells in the elderly (Shi et al., 2005), who are hence more susceptible to infection with encapsulated bacteria. It has been also shown a not significant increase in the expression of IgG and IgA on switched memory B cells from old donors (Buffa et al., 2011), although the relative proportions of the different isotypes of memory cells mirror the relative proportion of serum immunoglobulin of the different isotypes (Listì et al., 2006). Moreover, together with the switched immunoglobulins expression, evaluating the number of somatic mutations in the $\operatorname{IgG} \mathrm{VH}$ regions of $\operatorname{IgD}^{-} \mathrm{CD} 27^{+}$and $\operatorname{IgD}^{-} \mathrm{CD} 27^{-}$ $B$ cells in young and elderly donors, it has been estimated the effect of ageing on $B$ cell receptor hypermutation. The results have shown that, in both young and elderly subjects, $\operatorname{IgG}^{+} \operatorname{IgD}^{-} \mathrm{CD} 27^{-}$ DN memory B cells have significant fewer mutations (Table 3 ) than $\mathrm{IgG}^{+} \operatorname{IgD}^{-} \mathrm{CD} 27^{+}$switched memory B lymphocytes, although the rate of mutations observed in the DN B cell subset of old people is significantly reduced when compared to the rate of mutations observed in DN cells from young subjects. Moreover, there were no differences between the two age groups in the $\operatorname{IgG}^{+} \mathrm{IgD}^{-} \mathrm{CD} 27^{+}$ switched memory B cell compartment (Buffa et al., 2011).

The increase of the DN memory B cells in the elderly (Bulati et al., 2011; Colonna-Romano et al., 2009), together with the reduced rate of mutation, also described by Fecteau et al. (2006), might be due to the disconnected generation of these cells from germinal centres, as it has been demonstrated that ageing negatively affects the germinal centre formation in secondary lymphoid tissues (William et al., 2002). The hypothesis is that, $\operatorname{IgD}^{-} \mathrm{CD} 27^{-} \mathrm{DN}$ B cells could derive from $\mathrm{IgD}^{-} \mathrm{CD} 27^{+}$memory switched B cells, which have lost CD27 expression, or, alternatively, due to their low number of SHM, DN B cells could directly originate from $\mathrm{IgD}^{+} \mathrm{CD} 27^{-}$naïve $\mathrm{B}$ cells that are 
Table 3

Phenotypic and molecular characteristics of IgD-CD27- DN/LM B cells in the elderly.

\begin{tabular}{|c|c|c|}
\hline Characteristics & Meaning & References \\
\hline Switched $\operatorname{sIg}(\operatorname{IgG}, \operatorname{Ig} A)$ & \multirow[t]{2}{*}{ Memory cells } & \multirow{3}{*}{$\begin{array}{l}\text { Colonna-Romano et al } \\
\text { (2009) }\end{array}$} \\
\hline Short Telomeres & & \\
\hline Lower Expression of Co-stimulatory Molecules & Do not act as APC & \\
\hline Reduced SHM & $\begin{array}{l}\text { DN B cells could derive from memory switched B cells, } \\
\text { which have lost CD27 expression, or, alternatively, DN B } \\
\text { cells could directly originate from naïve B cells that are } \\
\text { triggered by polyclonal stimuli }\end{array}$ & Buffa et al. (2011) \\
\hline Not Impaired GrB Production & Effector Function & \multirow[t]{2}{*}{ Bulati et al. (2014) } \\
\hline $\mathrm{CCR}^{+} \mathrm{CCR}^{+}$ & Pro-inflammatory Trafficking Phenotype & \\
\hline Increased miR-155, miR-16 and miR-93 & Senescent-Associated Secretory Phenotype (SASP) & \multirow[t]{4}{*}{ Frasca et al. (2017) } \\
\hline Increased TNF- $\alpha /$ IL- 6 mRNA & & \\
\hline Increased p $16^{\mathrm{INK} 4} \mathrm{mRNA}$ & & \\
\hline spontaneous phosphorylation of AMPK and $\mathrm{p}^{3}$ & & \\
\hline
\end{tabular}

triggered by polyclonal stimuli, as microbial products (Bulati et al., 2011; Colonna-Romano et al., 2009; Palma et al., 2014).

Using another cellular approach, that takes into account the developmental B cell markers, CD24 and CD38, it is possible to identify four different B cell population, as (1) $\mathrm{CD} 19^{+} \mathrm{CD} 38^{\text {high }} \mathrm{CD} 24^{\text {high }}$, transitional $\mathrm{B}$ cells, that include immature and $\operatorname{IgD}^{+} \mathrm{CD} 27^{-}$naïve B cells, (2) $\mathrm{CD} 19^{+} \mathrm{CD} 38^{\text {int }} \mathrm{CD} 24^{\text {int }}$, defined as mature naïve $\mathrm{B}$ cells,

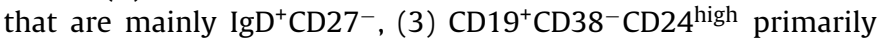
memory B cells, which show a variety of different memory phenotypes, including $\mathrm{IgD}^{-} \mathrm{CD} 27^{-}$DN B cells, and (4) a not thus far described $\mathrm{CD} 19^{+} \mathrm{CD} 38^{-} \mathrm{CD} 24^{-}$population of $\mathrm{B}$ cells, which include both $\operatorname{IgD}^{-} \mathrm{CD}_{27} 7^{+}$switched memory and $\operatorname{IgD}^{-} \mathrm{CD} 27^{-}$DN B (Blair et al., 2010; Buffa et al., 2013; Carsetti et al., 2004). Interestingly, it has been demonstrated an age-related increase of these $\mathrm{CD}^{1}{ }^{+} \mathrm{CD} 38^{-} \mathrm{CD}^{-} 4^{-} \mathrm{B}$ cells (Table 1 ), which also seem to be involved in inflammation, as they are able to produce TNF- $\alpha$ (Buffa et al., 2013; Palma et al., 2014).

Moreover, recently, an age-related accumulation of a subset of $B$ cells, with unique phenotypic and functional features, termed age-associated $B$ cells $(A B C)$, that resemble $\operatorname{IgD}^{-} \mathrm{CD} 27^{-}$DN B cells, has been identified in mice and humans (Table 1) (Naradikian et al., 2016; Rubtsova et al., 2015). These cells are characterized by a T-BET driven transcriptional program, robust responsiveness to TLR7 and TLR9 ligands, and a propensity for IgG2a production. Despite $\mathrm{ABC}\left(\mathrm{CD} 19^{+} \mathrm{CD} 11 \mathrm{~b}^{+} \mathrm{CD} 11 \mathrm{c}^{+} \mathrm{CD} 21^{-} \mathrm{IgD}^{-}\right)$and $\mathrm{DN}$ $\left(\mathrm{CD}_{19}{ }^{+} \mathrm{IgG}^{+} \mathrm{IgD}^{-} \mathrm{CD}^{-} 7^{-}\right)$B cells cannot be compared, due to their different phenotypic characterization, they share some characteristics. Indeed, it has been proposed that $\mathrm{ABC}$ are a memory subset generated by nucleic acid containing antigens in the context of a pro-inflammatory cytokine milieu, are consider exhausted $B$ cells and they also arise during humoral autoimmune diseases (Naradikian et al., 2016; Rubtsova et al., 2015). Furthermore, an in vivo study has suggested that these cells are also an abundant source of TNF- $\alpha$ and inhibit survival of B-cell precursors (Ratliff et al., 2013).

The conflicting data in the literature, regarding the distribution of naïve/memory B cells in the elderly, and the presence of exhausted/senescent B cells with different phenotypes (DN, $\mathrm{CD} 24^{-} \mathrm{CD} 38^{-}$or $\mathrm{ABC}$ ), strengthen the idea of using shared markers to uniquely characterize the memory/naïve $B$ cell subpopulations (Kaminski et al., 2012).

\subsection{DN B lymphocytes are exhausted/senescent cells involved in inflamm-ageing, but, in some circumstances, might be 'active'}

$\operatorname{IgD}^{-} \mathrm{CD} 27^{-} \mathrm{DN} B$ cells have been also reported to be expanded, in percentage, in other models of "chronic stimulation", as in patients affected by Systemic Lupus Erythematosus (SLE) or Rheumatoid Arthritis (RA), in HIV-infected people, in subjects challenged with Respiratory Syncytial Virus and in Alzheimer's disease (AD) patients (Bulati et al., 2015; Fecteau et al., 2006; Mahmood et al., 2015; Palma et al., 2014; Sanz et al., 2008; Wei et al., 2007). So, probably, the increase in percentage of the DN B cell population observed in the elderly, might be related to the typical inflammatory microenvironment, characterized by a general increase in plasma levels of pro-inflammatory cytokines and other inflammatory mediators (inflamm-ageing). Notably, neither in the elderly nor in the abovementioned models of chronic inflammation, it has been reported the increase of the absolute number of DN B cells, as these conditions are characterized by lymphopenia. It can be stated that, as demonstrated for T cells (Pawelec, 2014a,b), DN B cells could be senescent/exhausted memory cells, and their expansion might be the manifestation of a physiologic modification timerelated (ageing) or a pathologic deregulation (SLE or RA patients, HIV infected subjects, AD patients) of the immune system.

Although the different phenotype approach used to identify naïve and memory B cells, there is a consensus according to the agerelated increase in percentage of late/exhausted memory B cells or antigen experienced pro-inflammatory B cell subsets (Buffa et al., 2013; Bulati et al., 2011; Colonna-Romano et al., 2009; Fecteau et al., 2006; Naradikian et al., 2016), which could be the by-product and/or the cause of inflamm-ageing. The term "exhausted" could be reported to terminally differentiated-senescent cells, that express the cell cycle regulator $\mathrm{p} 16^{\mathrm{INK} 4}$, which induces cell cycle arrest, even these cells remain metabolically active, and undergo distinct phenotypic alterations, as well as telomere shortening and decondensation of peri-centromeric satellite DNA (Farr et al., 2016; Pinti et al., 2016). These cells accumulate in multiple tissues with ageing, and produce dysfunctional molecules (Farr et al., 2016; Pinti et al., 2016).

As demonstrated, $\mathrm{IgD}^{-} \mathrm{CD} 27^{-}$peripheral B cells, namely senescent/exhausted B cells (Bulati et al., 2011; Colonna-Romano et al., 2009; Frasca et al., 2017; Kaminski et al., 2012), have shorter telomeres (see below), show lower expression of co-stimulatory molecules (Table 3) (Colonna-Romano et al., 2009), seem to be pre-activated, as they produce pro-inflammatory cytokines before stimulation (Frasca et al., 2012a), and are "refractory" to undergo in vitro class switch when stimulated by antigens and mitogens (Fig. 1) (Buffa et al., 2011, 2013; Colonna-Romano et al., 2009; Fecteau et al., 2006; Pinti et al., 2016). So, the hallmark of senescent cells is the acquisition of a senescence-associated phenotype, which involves the chronic secretion of numerous pro-inflammatory cytokines, chemokines, growth factors and proteases (Pinti et al., 2016).

Concerning the difference in telomere length between naïve and memory B cells in humans, the studies are controversial. Indeed, Colonna-Romano et al. (2009), reported that memory B cells have shorter telomeres than naïve B cells, while Son et al. (2003) reported that naïve and memory B cells have similar telomere length, whereas the first study shown that memory B cells have 


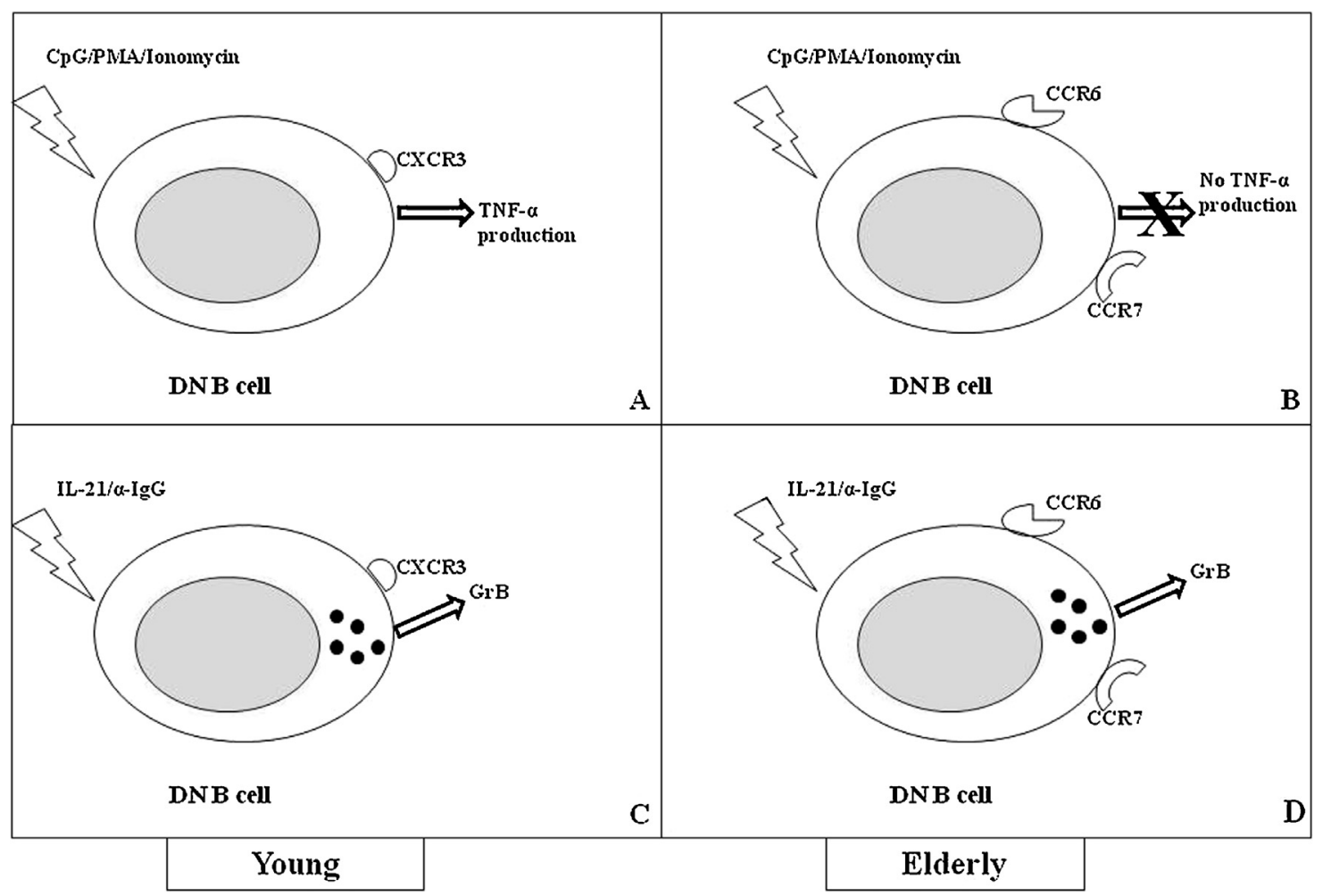

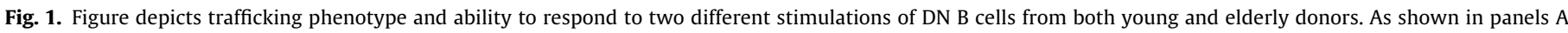

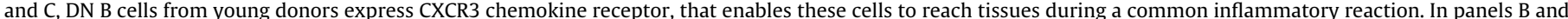

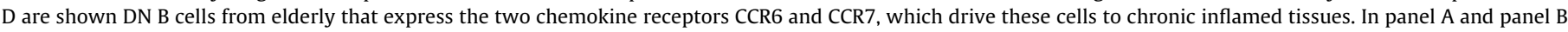

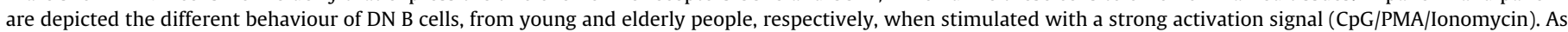

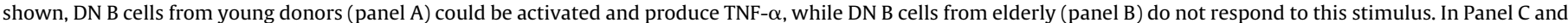
$\mathrm{D}$ are shown as, both in young and elderly, DN B cells are able to produce GrB, when stimulated with human recombinant IL-21 and anti-human IgG.

longer telomeres than naïve B cells (Martens et al., 2002). Probably, these controversial data may be due to the different approach used to differentiate naive from memory B cells in the cited studies.

There is no doubt that a link between "inflamm-ageing" and acquired immune responses may be identified, both in the production of chemokines, and in the expression of their receptors. Although there is much promiscuity within the chemokine network, it is well known that certain combinations of chemokines and their receptors enable immune cells to reach specific tissues (Kunkel and Butcher, 2003; Perez-Andres et al., 2010; Stein and Nombela-Arrieta, 2005). It has been reported that, with ageing, B cells undergo a remodelling on the expression of their chemokine receptors profile, and in particular in the memory compartment, including $\mathrm{IgD}^{-} \mathrm{CD} 27^{-}$senescent/exhausted DN memory B cells, which seem to be able to reach chronic inflamed tissues (Bulati et al., 2014). Indeed, it has been shown that IgD ${ }^{-} \mathrm{CD}^{2} 7^{-} \mathrm{DN}$ B cells from young donors, express CXCR3 (Fig. 1), a chemokine receptor that consents cells to reach the inflammatory sites, where its ligand, monokine-induced by interferon- $\gamma$ (CXCL9) and IP-10 (CXCL10), are highly expressed during a common inflammatory reaction (Farber, 1997; Kunkel and Butcher, 2003). Surprisingly, with ageing, DN B cells lose the expression of CXCR3 molecule, but express higher levels of CCR6 and CCR7 (Fig. 1, Table 3), which, as demonstrated (Comerford et al., 2010; McNamee et al., 2013; Müller and Lipp, 2003; Schutyser et al., 2003; Welsh-Bacic et al., 2010), are involved in the migration to the inflammatory sites, in this case, in chronic inflamed tissues. These are interesting data that could be discussed in terms of "inflamm-ageing". The hypothesis is that the typical inflammatory milieu of aged people influences the trafficking ability of B cells rendering them more sensitive to both cytokines and others pro-inflammatory molecules which are over- produced in the elderly (Salvioli et al., 2013; Singh and Newman, 2011). This hypothesis is also supported by results obtained in a cohort of highly inflamed AD patients. In this study (Bulati et al., 2015 ) it has been demonstrated that in AD patients there is a reduction of both total and naïve $B$ cells and the increase of DN memory B cells. Moreover, DN B cells express higher levels of both CCR6 and CCR7 chemokine receptors when compared to healthy elderly. Interestingly, these data are shown only in severe $\mathrm{AD}$ patients and not in mild AD subjects (Bulati et al., 2015).

It is well known that B cells, with an appropriate stimulation, are able to produce cytokines, chemokines or other effector molecules (Hagn and Jahrsdörfer, 2012; Klinker and Lundy, 2012; Lund, 2008; Lund and Randall, 2010; Rosser and Mauri, 2015). In previously papers it has been shown that $\operatorname{IgD}^{-} \mathrm{CD}_{27}^{-}$DN B cells seem to be refractory to undergo in vitro activation. Indeed, stimulating DN B cells, with $\mathrm{CpG}$, that binds TLR9, or with a polyclonal mitogen of $B$ cells that binds the $B$ cell receptors (anti-BCR), of both young and elderly subjects, these cells are not able to be activated and to produce cytokines (Colonna-Romano et al., 2009). Moreover, using a strong activation signal, as CpG/PMA/Ionomycin, DN $B$ cells from young donors could be activated and produce TNF$\alpha$, while DN B cells from elderly do not respond to this stimulus (Fig. 1) (Buffa et al., 2011). Interestingly, the in vitro stimulation of the $\mathrm{CD} 24^{-} \mathrm{CD} 38^{-} \mathrm{B}$ cells, that include both switched memory $\left(\operatorname{IgD}^{-} \mathrm{CD} 27^{+}\right)$and $\mathrm{DN}\left(\operatorname{IgD}^{-} \mathrm{CD}^{2} 7^{-}\right) \mathrm{B}$ cells, using the strong activation signal (CpG/PMA/Ionomycin), make these cells able to produce higher amount of the pro-inflammatory cytokine TNF- $\alpha$, but without significant differences between young and old people (Buffa et al., 2013). As CD38- CD24- B cell are largely expanded in elderly, it can be speculated that also $\mathrm{CD}_{24}{ }^{-} \mathrm{CD} 38^{-}$could contribute to "inflamm-aging". 
So, the ability of B cells to produce effector molecules depends both on the triggering of its receptors (BCR, CD40 or TLRs), and the microenvironment (Hagn and Jahrsdörfer, 2012; Klinker and Lundy, 2012; Lund, 2008; Lund and Randall, 2010; Rosser and Mauri, 2015). In the last years, it has been demonstrated that the combination of the pro-inflammatory IL-21 and BCR stimulation, in the absence of CD40 triggering, enables B cells to produce and secrete the active form of the cytotoxic serine protease granzyme B (GrB), that plays a critical role in early anti-viral immune responses, in the regulation of autoimmune mechanisms and in cancer immune-surveillance (Hagn and Jahrsdörfer, 2012). Moreover, both in elderly (Agrawal et al., 2012) and in SLE patients (Dolff et al., 2011), which shown increased percentage of IgD $^{-}$CD27 $^{-}$ DN B cells (Colonna-Romano et al., 2009; Sanz et al., 2008; Wei et al., 2007), increased levels of IL-21 have been reported. In a recent paper it has been demonstrated that, when stimulated with human recombinant IL-21 and anti-human IgG (BCR triggering), DN B cells from both young and elderly people, produce GrB (Bulati et al., 2014), without any difference between the two age groups (Fig. 1). So, as previously discussed, in elderly, $\operatorname{IgD}^{-} \mathrm{CD} 27^{-}$DN B cells are increased and show a trafficking phenotype that consent them to reach chronic inflamed tissues or tertiary lymph node. As their capacity to produce GrB is not age-impaired and, almost certainly, in other condition they could produce other kinds of proinflammatory molecules, they certainly exert a biological function, probably having an active role in inflamm-ageing and immunosenescence (Table 3 ).

It is important to stress that, not only the phenotypic modifications and the ability to respond to different stimuli, but also the functional quality of the B cell compartment certainly influences the individual's response. On this purpose, it has been above discussed that unstimulated total B cells from elderly produce significantly higher levels of TNF- $\alpha$ than those produced by young subjects, and these negatively correlates with B cells function (Frasca et al., 2014). In a recent paper (Frasca et al., 2017), it has been investigated the capacity of naïve/memory B cell subsets to express multiple senescent-associated secretory phenotype markers (SASP), such as cell senescence ( $\left.\mathrm{p} 16^{\mathrm{INK} 4}\right)$, miRNAs (miR-155, miR-16, miR93) and pro-inflammatory cytokines (TNF- $\alpha$, IL-6). The authors have demonstrated that unstimulated memory, but not naïve $B$ cells, from both young and elderly people, express the mRNA for TNF- $\alpha$, IL- 6 and $\mathrm{p} 16^{\mathrm{INK} 4}$, and the pro-inflammatory miR155, miR-16 and miR-93. Levels of these molecules were higher in B cells from elderly compared to young and, among memory $B$ cell subsets, $\mathrm{IgD}^{-} \mathrm{CD} 27^{-}$DN B cells, also known as late memory (LM), showed the highest levels of SASP markers (Table 3), which are associated with the activation of NF-kB transcription activity, in the absence of cell activation (Frasca et al., 2017). Moreover, DN/LM B cells also shown spontaneous phosphorylation of AMPK and p38MAPK (Table 3) (Frasca et al., 2017), which are associated with cell exhaustion and senescent phenotype, suggesting that a reprogramming of cellular metabolism occurs in senescent cells, and this metabolic adaption induces global changes in cellular metabolic programs through the regulation of gene transcription (Blagih et al., 2012).

\section{Conclusion}

It is known that inflammation is important for survival in the earlier stage of life to fight infections and for the tissues repair, but it can have adverse and detrimental effects on aged individuals ("antagonistic pleiotropic theory", Goto, 2008). Indeed, as discussed, elderly are characterized by a subclinical chronic inflammatory condition termed "inflamm-ageing", which contributes to the development of a variety of age-associated diseases such as metabolic, cardiovascular, autoimmune and neurodegenerative diseases and cancer (Bucci et al., 2014; Frasca and Blomberg, 2016; Fulop et al., 2016; Grasse et al., 2016; Grubeck-Loebenstein et al., 2009; Johnson and Cambier, 2004; Rubtsova et al., 2015; Salvioli et al., 2013). The condition of inflamm-ageing provides a continuous mild antigenic challenge that leads to a progressive stimulation, or depletion, of the immune system cells and to filling of the immunological space by activated/exhausted lymphocytes with altered functions (Bulati et al., 2011, 2014; Fulop et al., 2016; Larbi and Fulop, 2014; Naradikian et al., 2016; Pawelec, 2014a,b; Pinti et al., 2016; Rubtsova et al., 2015).

It is clear that ageing is a complex process that is influenced by multiple factors at multiple levels. Nonetheless, it is undeniable that inflammation plays an important role in this phenomenon. It was widely discussed above as inflamm-ageing seems to have a pivotal role on the age-related changes at systemic, molecular and cellular levels that leads to B cell compartment impairment. Indeed, inflamm-ageing contributes in all stages of development and maturation of B cells, from B lymphopoiesis to plasma cells differentiation, but the precise interplay between inflamm-ageing and the age-related changes of $\mathrm{B}$ cell compartment, remains to be elucidated. A pivotal role in the impairment of B cell branch of the immune system is certainly played by senescent/exhausted DN B cells. Indeed, as discussed, these cells are increased in the elderly, and in other models of chronic inflammation, and they show a pro-inflammatory trafficking and a SASP phenotype. It is also known that the age-related accumulation of senescent cells represents a favourable environment for the development of proinflammatory age-related diseases (Campisi, 2003, 2011). These results make the study of $B$ cells in the aged an important tool for monitoring, not only the immunosenescence phenomenon per se, but, as these modifications reflect the inflammatory events, also the chronic inflammatory diseases, such as cancers, HIV, AD and autoimmune phenomena, and the effectiveness of vaccines.

As discussed, healthy elderly and individual with chronic diseases, as HIV infected patients, shared similar features of B cells impairment, as loss of protective immunity and poor response to vaccinations. As in elderly, impaired AID expression and poor effectiveness of influenza vaccination has been also shown in HIVpositive individuals (Cagigi et al., 2013a), where, also the increased frequency of $\operatorname{IgD}^{-} \mathrm{CD} 27^{-} \mathrm{DN}$ B cells is negatively related to the strength of humoral response to the vaccine (Cagigi et al., 2013b). Moreover, another study correlates the impaired antibody response to influenza vaccination, in both HIV infected or uninfected ageing women, to inflammation, measured by high levels of plasma IL-21 and TNF- $\alpha$ (Parmigiani et al., 2013). All these data suggest that, the evaluation of the AID expression, the frequency of DN B cells and the levels of pro-inflammatory cytokines, could be useful tools for vaccination design, in terms of number of vaccine doses, in order to achieve immune protection in both elderly and chronic inflamed individuals.

Further evidence demonstrating the pro-inflammatory nature of DN B cells, and their potential role as useful marker for the monitoring of pro-inflammatory diseases, is coming from a recent clinical study on RA patients, with a significantly expanded population of DN B cells (Mahmood et al., 2015). The authors have studied the modulation of $\mathrm{IgD}^{-} \mathrm{CD} 27^{-}$DN B cells after treating their patients with the anti-IL6R drug Tocilizumab. They obtained a significant reduction of this subpopulation. This result confirms the role of inflammation as the cause/effect of DN B cells increase and, in the meantime, suggests DN B cell as an important candidate marker for the monitoring of the pharmacological therapy in RA and, hopefully, in other autoimmune or inflammatory disorders.

Moreover, the molecular modifications of B cells could be used to monitor both cancer and autoimmune diseases in the elderly. As it has been demonstrated an age-related increase of miR-155 
and miR16, directly related to the inflammatory status of elderly (Frasca et al., 2015a, 2017), monitoring these two biomarkers, in both total and DN B cells, could have a prognostic significance for B cell cancer (Due et al., 2016), and autoimmune disorders (Churov et al., 2015).

Finally, in the last years, altered regulation of the signalling pathways has been suggested to be one of the most important cause of immunosenescence, and the modulation of these pathways represent a major challenge to "restore" the immune response to functional levels. Indeed, alterations in the stimulatory and/or inhibitory signalling have been demonstrated to occur in the immune responses of both innate and acquired immunity during ageing, in particular in neutrophils and Tymphocytes, and these events lead to a less efficient function of the immune system (Fulop et al., 2014, 2016). The authors suggest that combined approaches that consist of maintaining adequate early feed-forward activation while down-regulating feedback inhibition would be beneficial in restoring several T cell functions in ageing (Fulop et al., 2014, 2016). It can be speculate that also for $B$ cells it could be possible to restore their impaired function. For example, by acting on the level of phosphorylation of AMPK or p38MAPK, it could be evaluated in vitro if class switch and antibody production will be improved.

\section{References}

Aberle, J.H., Stiasny, K., Kundi, M., Heinz, F.X., 2013. Mechanistic insights into the impairment of memory B cells and antibody production in the elderly. Age 35 (2), 371-381.

Ademokun, A., Wu, Y.C., Martin, V., Mitra, R., Sack, U., Baxendale, H., Kipling, D., Dunn-Walters, D.K., 2011. Vaccination-induced changes in human B-cell repertoire and pneumococcal IgM and IgA antibody at different ages. Aging Cell 10, 922-930.

Agrawal, A., Su, H., Chen, J., Osann, K., Agrawal, S., Gupta, S., 2012. Increased IL-21 secretion by aged CD4 + T cells is associated with prolonged STAT-4 activation and CMV seropositivity. Aging 4 (9), 648-659.

Avery, P., Barzilai, N., Benetos, A., Bilianou, H., Capri, M., Caruso, C., Franceschi, C., Katsiki, N., Mikhailidis, D.P., Panotopoulos, G., Sikora, E., Tzanetakou, I.P., Kolovou, G., 2014. Ageing, longevity, exceptional longevity and related genetic and non genetic markers: panel statement. Curr. Vasc. Pharmacol. 12 (5), 659-661.

Baldridge, M.T., King, K.Y., Boles, N.C., Weksberg, D.C., Goodell, M.A., 2010. Quiescent haematopoietic stem cells are activated by IFN- $\gamma$ in response to chronic infection. Nature 465 (7299), 793-797.

Beerman, I., Bhattacharya, D., Zandi, S., Sigvardsson, M., Weissman, I.L., Bryder, D., Rossi, D.J., 2010. Functionally distinct hematopoietic stem cells modulate hematopoietic lineage potential during aging by a mechanism of clonal expansion. Proc. Natl. Acad. Sci. U. S. A. 107 (12), 5465-5470.

Bernasconi, N.L., Traggiai, E., Lanzavecchia, A., 2002. Maintenance of serological memory by polyclonal activation of human memory B cells. Science 298 (5601), 2199-2202.

Blagih, J., Krawczyk, C.M., Jones, R.G., 2012. LKB1 and AMPK: central regulators of lymphocyte metabolism and function. Immunol. Rev. 249 (1), 59-71.

Blair, P.A., Noreña, L.Y., Flores-Borja, F., Rawlings, D.J., Isenberg, D.A., Ehrenstein, M.R., Mauri, C., 2010. CD19(+)CD24 (hi)CD38(hi) B cells exhibit regulatory capacity in healthy individuals but are functionally impaired in systemic lupus erythematosus patients. Immunity 32 (1), 129-140.

Bruunsgaard, H., 2006. The clinical impact of systemic low-level inflammation in elderly populations.With special reference to cardiovascular disease dementia and mortality. Dan. Med. Bull. 53, 285-309.

Bucci, L., Ostan, R., Giampieri, E., Cevenini, E., Pini, E., Scurti, M., Vescovini, R. Sansoni, P., Caruso, C., Mari, D., Ronchetti, F., Borghi, M.O., Ogliari, G., Grossi, C., Capri, M., Salvioli, S., Castellani, G., Franceschi, C., Monti, D., 2014. Immune parameters identify Italian centenarians with a longer five-year survival independent of their health and functional status. Exp. Gerontol. 54, 14-20.

Buffa, S., Bulati, M., Pellicanò, M., Dunn-Walters, D.K., Wu, Y.C., Candore, G., Vitello, S., Caruso, C., Colonna-Romano, G., 2011. B cell immunosenescence: different features of naive and memory B cells in elderly. Biogerontology 12 (5), 473-483.

Buffa, S., Pellicanò, M., Bulati, M., Martorana, A., Goldeck, D., Caruso, C., Pawelec, G., Colonna-Romano, G., 2013. A novel B cell population revealed by a CD38/CD24 gating strategy: CD38(-)CD24(-) B cells in centenarian offspring and elderly people. Age (Dordr.) 35 (5), 2009-2024.

Bulati, M., Buffa, S., Candore, G., Caruso, C., Dunn-Walters, D.K., Pellicanò, M., Wu, Y.C., 2011. Colonna Romano G. B cells and immunosenescence: a focus on IgG + IgD-CD27- (DN) B cells in aged humans. Ageing Res. Rev. 10, 274-284.

Bulati, M., Buffa, S., Martorana, A., Candore, G., Lio, D., Caruso, C., Colonna-Romano, G., 2014. Trafficking phenotype and production of granzyme B by double negative B cells $(\operatorname{Ig} G(+) \operatorname{IgD}(-) C D 27(-))$ in the elderly. Exp. Gerontol. 54, $123-129$

Bulati, M., Buffa, S., Martorana, A., Gervasi, F., Camarda, C., Azzarello, D.M., Monastero, R., Caruso, C., Colonna-Romano, G., 2015. Double negative (IgG + IgD-CD27-) B cells are increased in a cohort of moderate-severe Alzheimer's disease patients and show a pro-inflammatory trafficking receptor phenotype. J. Alzheimers Dis. 44 (4), 1241-1251.

Cagigi, A., Pensieroso, S., Ruffin, N., Sammicheli, S., Thorstensson, R., Pan-Hammarström, Q., Hejdeman, B., Nilsson, A., Chiodi, F., 2013a. Relation of activation-induced deaminase (AID) expression with antibody response to A(H1N1)pdm09 vaccination in HIV-1 infected patients. Vaccine 31, 2231-2237.

Cagigi, A., Rinaldi, S., Di Martino, A., Manno, E.C., Zangari, P., Aquilani, A., Cotugno, N., Nicolosi, L., Villani, A., Bernardi, S., Donatelli, I., Pahwa, S., Rossi, P., Palma, P., 2013b. Premature immune senescence during HIV-1 vertical infection relates with response to influenza vaccination. J. Allergy Clin. Immunol. (PMID:24290278).

Campisi, J., 2003. Cancer and ageing: rival demons? Nat. Rev. Cancer 3, 339-349.

Campisi, J., 2011. Cellular senescence: putting the paradoxes in perspective. Curr. Opin. Genet Dev. 21, 107-112.

Cancro, M.P., Hao, Y., Scholz, J.L., Riley, R.L., Frasca, D., Dunn-Walters, D.K., Blomberg, B.B., 2009. B cells and aging: molecules and mechanisms. Trends Immunol. 30 (7), 313-318.

Carsetti, R., Rosado, M.M., Wardmann, H., 2004. Peripheral development of B cells in mouse and man. Immunol. Rev. 197, 179-191.

Cevenini, E., Caruso, C., Candore, G., Capri, M., Nuzzo, D., Duro, G., Rizzo, C., Colonna-Romano, G., Lio, D., Di Carlo, D., Palmas, M.G., Scurti, M., Pini, E., Franceschi, C., Vasto, S., 2010. Age-related inflammation: the contribution of different organs, tissues and systems: how to face it for therapeutic approaches. Curr. Pharm. Des. 16 (6), 609-618.

Challen, G.A., Boles, N.C., Chambers, S.M., Goodell, M.A., 2010. Distinct hematopoietic stem cell subtypes are differentially regulated by TGF- $\beta 1$. Cell Stem Cell 6 (3), 265-278.

Chan, G.K., Duque, G., 2002. Age-related bone loss: old bone, new facts. Gerontology 48 (2), 62-71.

Christensen, K., McGue, M., Petersen, I., Jeune, B., Vaupel, J.W., 2008. Exceptional longevity does not result in excessive levels of disability. Proc. Natl. Acad. Sci. U. S. A. 105, 13274-13279.

Churov, A.V., Oleinik, E.K., Knip, M., 2015. MicroRNAs in rheumatoid arthritis: altered expression and diagnostic potential. Autoimmun. Rev. 14 (11), 1029-1037

Colonna-Romano, G., Bulati, M., Aquino, A., Pellicanò, M., Vitello, S., Lio, D., Candore, G., Caruso, C., 2009. A double-negative (IgD-CD27-) B cell population is increased in the peripheral blood of elderly people. Mech. Ageing Dev. 130, 681-690.

Comerford, I., Bunting, M., Fenix, K., Haylock-Jacobs, S., Litchfield, W., Harata-Lee, Y., Turvey, M., Brazzatti, J., Gregor, C., Nguyen, P., Kara, E., McColl, S.R., 2010. An immune paradox: how can the same chemokine axis regulate both immune tolerance and activation?: CCR6/CCL20: a chemokine axis balancing immunological tolerance and inflammation in autoimmune disease. Bioessays 32 (12), 1067-1076.

Derhovanessian, E., Maier, A.B., Beck, R., Jahn, G., Hähnel, K., Slagboom, P.E., de Craen, A.J., Westendorp, R.G., Pawelec, G., 2010. Hallmark features of immunosenescence are absent in familial longevity. Immunology 185 , 4618-4624

Derhovanessian, E., Theeten, H., Hahnel, K., Van Damme, P., Cools, N., Pawelec, G., 2013. Cytomegalovirus-associated accumulation of latedifferentiatedCD4 T-cells correlates with poor humoral response toinfluenza vaccination. Vaccine 31, 685-690.

Dolff, S., Abdulahad, W.H., Westra, J., Doornbos-van der Meer, B., Limburg, P.C., Kallenberg, C.G., Bijl, M., 2011. Increase in IL-21 producing T-cells in patients with systemic lupus erythematosus. Arthritis Res. Ther. 13 (5), R157.

Due, H., Svendsen, P., Bødker, J.S., Schmitz, A., Bøgsted, M., Johnsen, H.E., El-Galaly, T.C., Roug, A.S., Dybkær, K., 2016. miR-155 as a Biomarker in B-Cell Malignancies. Biomed. Res. Int. 2016 (9513037).

Dunn-Walters, D.K., Ademokun, A.A., 2010. B cell repertoire and ageing. Curr. Opin. Immunol. 22 (4), 514-520.

Dunn-Walters, D.K., 2016. The ageing human B cell repertoire: a failure of selection? Clin. Exp. Immunol. 183 (1), 50-56.

Essers, M.A., Offner, S., Blanco-Bose, W.E., Waibler, Z., Kalinke, U., Duchosal, M.A., Trumpp, A., 2009. IFN $\alpha$ activates dormant haematopoietic stem cells in vivo. Nature 458 (7240), 904-908.

Farber, J.M., 1997. Mig and IP-10: CXC chemokines that target lymphocytes. J. Leukoc. Biol. 61 (3), 246-257.

Farr, J.N., Fraser, D.G., Wang, H., Jaehn, K., Ogrodnik, M.B., Weivoda, M.M., Drake, M.T., Tchkonia, T., LeBrasseur, N.K., Kirkland, J.L., Bonewald, L.F., Pignolo, R.J., Monroe, D.G., Khosla, S., 2016. Identification of senescent cells in the bone microenvironment. J. Bone Miner. Res., http://dx.doi.org/10.1002/jbmr.2892.

Fecteau, J.F., Cote, G., Neron, S., 2006. A new memory CD27-IgG+ B cell population in peripheral blood expressing VH genes with low frequency of somatic mutation. J. Immunol. 177, 3728-3736.

Franceschi, C., Campisi, J., 2014. Chronic inflammation (inflammaging) and its potential contribution to age-associated diseases. J. Gerontol. A BiolSci. Med. Sci. 69, S4-S9.

Frasca, D., Blomberg, B.B., 2014. B cell function and influenza vaccine responses in healthy aging and disease. Curr. Opin. Immunol. 29, 112-118. 
Frasca, D., Blomberg, B.B., 2016. Inflamm-aging decreases adaptive and innate immune responses in mice and humans. Biogerontology 17 (1), 7-19.

Frasca, D., Landin, A.M., Lechner, S.C., Ryan, J.G., Schwartz, R., Riley, R.L., Blomberg, B.B., 2008. Aging down-regulates the transcription factor E2A, activation-induced cytidine deaminase, and Ig class switch inhuman B cells. J. Immunol. 180, 5283-5290.

Frasca, D., Diaz, A., Romero, M., Landin, A., Blomberg, B.B., 2011. Age effect on B cell and humoral immunity in humans. Ageing Res. Rev. 10 (3), 330-335.

Frasca, D., Romero, M., Diaz, A., Alter-Wolf, S., Ratliff, M., Landin, A.M., Riley, R.L., Blomberg, B.B., 2012a. A molecular mechanism for TNF- $\alpha$-mediated downregulation of B cell responses. J. Immunol. 188 (1), 279-286.

Frasca, D., Diaz, A., Romero, M., Phillips, M., Mendez, N.V., Landin, A.M., Blomberg, B.B., 2012b. Unique biomarkers for B-cell function predict the serum response to pandemic H1N1 influenza vaccine. Int. Immunol. 24, 175-182.

Frasca, D., Diaz, A., Romero, M., Mendez, N.V., Landin, A.M., Blomberg, B.B., 2013. Effects of age on H1N1-specific serum IgG1 and IgG3 levels evaluated during the 2011-2012 influenza vaccine season. Immun. Ageing 10, 14

Frasca, D., Diaz, A., Romero, M., Landin, A.M., Blomberg, B.B., 2014. High TNF-alpha levels in resting B cells negatively correlate with theirresponse. Exp. Gerontol. $54,116-122$.

Frasca, D., Diaz, A., Romero, M., Ferracci, F., Blomberg, B.B., 2015a. Micro-RNAs miR-155 and miR-16 decrease AID and E47 in B cells from elderly individuals. J. Immunol. 195 (5), 2134-2140.

Frasca, D., Diaz, A., Romero, M., Landin, A.M., Blomberg, B.B., 2015b. Cytomegalovirus (CMV) seropositivity decreases B cell responses to the influenza vaccine. Vaccine 33, 1433-1439.

Frasca, D., Diaz, A., Romero, M., Blomberg, B.B., 2016. The generation of memory B cells is maintained, but the antibody response is not, in the elderly after repeated influenza immunizations. Vaccine 34 (25), 2834-2840.

Frasca, D., Diaz, A., Romero, M., Blomberg, B.B., 2017. Human peripheral late/exhausted memory B cells express a senescent-associated secretory phenotype and preferentially utilize metabolic signalling pathways. Exp. Gerontol. 87, 113-120.

Fulop, T., Le Page, A., Fortin, C., Witkowski, J.M., Dupuis, G., Larbi, A., 2014. Cellular signalling in the aging immune system. Cuur. Opin. Immunol. 29, 105-111.

Fulop, T., Witkowski, J.M., Le Page, A., Fortin, C., Pawelec, G., Larbi, A., 2016. Intracellular signaling pathways: targets to reverse immunosenescence. Clin. Exp. Immunol., http://dx.doi.org/10.1111/cei.12836.

Gibson, K.L., Wu, Y.C., Barnett, Y., Duggan, O., Vaughan, R., Kondeatis, E., Nilsson, B.O., Wikby, A., Kipling, D., Dunn-Walters, D.K., 2009. B-cell diversity decreases in old age and is correlated with poor health status. Aging Cell 8 (1), 18-25.

Globerson, A., Effros, R.B., 2000. Ageing of lymphocytes and lymphocytes in the aged. Immunol. Today 21 (10), 515-521.

Goto, M., 2008. Inflammaging (inflammation + aging): a driving force for human aging based on an evolutionarily antagonistic pleiotropy theory? Biosci. Trends 2 (6), 218-230.

Grasse, M., Meryk, A., Schirmer, M., Grubeck-Loebenstein, B., Weinberger, B., 2016 Booster vaccination against tetanus and diphtheria: insufficient protection against diphtheria in young and elderly adults. Immun. Ageing 13 (1), 26.

Grubeck-Loebenstein, B., Della Bella, S., Iorio, A.M., Michel, J.P., Pawelec, G., Solana, R., 2009. Immunosenescence and vaccine failure in the elderly. Aging Clin. Exp. Res. 21, 201-209.

Guerrettaz, L.M., Johnson, S.A., Cambier, J.C., 2008. Acquired hematopoietic stem cell defects determine B-cell repertoire changes associated with aging. Proc. Natl. Acad. Sci. U. S. A. 105 (33), 11898-11902.

Gupta, S., Su, H., Bi, R., Agrawal, S., Gollapudi, S., 2005. Life and death of lymphocytes: a role in immunesenescence. Immun. Ageing 2, 12.

Hagn, M., Jahrsdörfer, B., 2012. Why do human B cells secrete granzyme B? Insights into a novel B-cell differentiation pathway. Oncoimmunology 1 (8), $1368-1375$.

Harris, D.P., Haynes, L., Sayles, P.C., Duso, D.K., Eaton, S.M., Lepak, N.M., Johnson, L.L., Swain, S.L., Lund, F.E., 2000. Reciprocal regulation of polarized cytokine production by effector B and T cells. Nat. Immunol. 1 (6), 475-482.

Haynes, L., Eaton, S.M., Burns, E.M., Randall, T.D., Swain, S.L., 2003. CD4 T cell memory derived from young naive cells functions well into old age, but memory generated from aged naive cells functions poorly. Proc. Natl. Acad. Sci. U. S. A. 100 (25), 15053-15058.

Henry, C.J., Casás-Selves, M., Kim, J., Zaberezhnyy, V., Aghili, L., Daniel, A.E., Jimenez, L., Azam, T., McNamee, E.N., Clambey, E.T., Klawitter, J., Serkova, N.J., Tan, A.C., Dinarello, C.A., De Gregori, J., 2015. Aging-associated inflammation promotes selection for adaptive oncogenic events in B cell progenitors. J. Clin. Invest. 125 (12), 4666-4680.

Jiang, N., He, J., Weinstein, J.A., Penland, L., Sasaki, S., He, X.S., Dekker, C.L., Zheng, N.Y., Huang, M., Sullivan, M., Wilson, P.C., Greenberg, H.B., Davis, M.M., Fisher, D.S., Quake, S.R., 2013. Lineage structure of the human antibody repertoire in response to influenza vaccination. Sci. Transl. Med. 5, 171 ra119.

Jin, R., Kaneko, H., Suzuki, H., Arai, T., Teramoto, T., Fukao, T., Kondo, N., 2008. Age-related changes in BAFF and APRIL profiles and upregulation of BAFF and APRIL expression in patients with primary antibody deficiency. Int. J. Mol. Med. $21,233-238$.

Johnson, S.A., Cambier, J.C., 2004. Ageing, autoimmunity and arthritis: senescence of the B cell compartment -implications for humoral immunity. Arthritis Res. Ther. 6, 131-139.

Kaminski, D.A., Wei, C., Qian, Y., Rosenberg, A.F., Sanz, I., 2012. Advances in human B cell phenotypic profiling. Front. Immunol. 3, 302-316.
Kannan, S., Kurupati, R.K., Doyle, S.A., Freeman, G.J., Schmader, K.E., Ertl, H.C., 2015 BTLA expression declines on B cells of the aged and is associated with low responsiveness to the trivalent influenza vaccine. 6(23), 19445-19455.

Khurana, S., Frasca, D., Blomberg, B.B., Golding, H., 2012. AID activity in Bcells strongly correlates with polyclonal antibody affinity maturation in vivo following pandemic 2009-H1N1 vaccination in humans. PLoS Pathog. 8 , e1002920.

Klinker, M.W., Lundy, S.K., 2012. Multiple mechanisms of immune suppression by B lymphocytes. Mol. Med. 18, 123-137.

Krabbe, K.S., Pedersen, M., Bruunsgaard, H., 2004. Inflammatory mediators in the elderly. Exp. Gerontol. 39, 687-699.

Kunkel, E.J., Butcher, E.C., 2003. Plasma-cell homing. Nat. Rev. Immunol. 3 (10), $822-829$.

López-Otín, C., Blasco, M.A., Partridge, L., Serrano, M., Kroemer, G., 2013. The hallmarks of aging. Cell 153, 1194-1217.

Larbi, A., Fulop, T., 2014. From truly naïve to exhausted senescent T cells: when markers predict functionality. Cytometry A 85 (1), 25-35.

Lawrie, C.H., 2013. MicroRNAs and lymphomagenesis: a functional review. Br. J. Haematol. 160 (5), 571-581.

Li, Y., Kim, J., Metter, E.J., Nguyen, H., Truong, T., Lustig, A., Ferrucci, L., Weng, N.P. 2016. Changes in blood lymphocyte numbers with age in vivo and their association with the levels of cytokines/cytokine receptors. Immun. Ageing 13 (24).

Listì, F., Candore, G., Modica, M.A., Russo, M., Di Lorenzo, G., Esposito-Pellitteri, M., Colonna-Romano, G., Aquino, A., Bulati, M., Lio, D., Franceschi, C., Caruso, C. 2006. A study of serum immunoglobulin levels in elderly persons that provides new insights into B cell immunosenescence. Ann. N. Y. Acad. Sci. 1089, 487-495.

Lund, F.E., Randall, T.D., 2010. Effector and regulatory B cells: modulators of CD4 ${ }^{+} \mathrm{T}$ cell immunity. Nat. Rev. Immunol. 10 (4), 236-247

Lund, F.E., 2008. Cytokine-producing B lymphocytes- key regulators of immunity. Curr. Opin. Immunol. 20, 332-338.

Müller, G., Lipp, M., 2003. Shaping up adaptive immunity: the impact of CCR7 and CXCR5 on lymphocyte trafficking. Microcirculation 10 (3-4), 325-334.

Magrone, T., Jirillo, E., 2013. The interaction between gut microbiota and age-related changes in immune function and inflammation. Immun. Ageing 10 (1), 31.

Mahmood, Z., Muhammad, K., Schmalzing, M., Roll, P., Dörner, T., Tony, H.P., 2015. CD27-IgD- memory B cells are modulated by in vivo interleukin-6 receptor (IL-6R) blockade in rheumatoid arthritis. Arthritis Res. Ther. 17, 61.

Martens, U.M., Brass, V., Sedlacek, L., Pantic, M., Exner, C., Guo, Y., Engelhardt, M., Lansdorp, P.M., Waller, C.F., Lange, W., 2002. Telomere maintenance in human B lymphocytes. Br. J. Haematol. 119 (3), 810-818.

McElhaney, J.E., Zhou, X., Talbot, H.K., Soethout, E., Bleackley, R.C., Granville, D.J., Pawelec, G., 2010. The unmet need in the elderly: how immunosenescence, CMV infection, co-morbidities and frailty are achallenge for the development of more effective influenza vaccines. Vaccine 30, 2060-2067.

McNamee, E.N., Masterson, J.C., Jedlicka, P., Collins, C.B., Williams, I.R., Rivera-Nieves, J., 2013. Ectopic lymphoid tissue alters the chemokine gradient, increases lymphocyte retention and exacerbates murine ileitis. Gut 62 (1), 53-62.

Naradikian, M.S., Hao, Y., Cancro, M.P., 2016. Age-associated B cells: key mediators of both protective and autoreactive humoral responses. Immunol. Rev. 269 (1), 118-129.

Oliveri, F., Rippo, M.R., Monsurrò, V., Salvioli, S., Capri, M., Procopio, A.D., Franceschi, C., 2013. MicroRNAs linking inflamm-aging, cellular senescence and cancer. Ageing Res. Rev. 12, 1056-1068.

Oxford, K.L., Dela Pena-Ponce, M.G., Jensen, K., Eberhardt, M.K., Spinner, A., Van Rompay, K.K., Rigdon, J., Mollan, K.R., Krishnan, V.V., Hudgens, M.G., Barry, P.A., De Paris, K., 2015. The interplay between immune maturation, age, chronic viral infection and environment. Immun. Ageing 12, 3.

Palma, P., Rinaldi, S., Cotugno, N., Santilli, V., Pahwa, S., Rossi, P., Cagigi, A., 2014. Premature B-cell senescence as a consequence of chronic immune activation. Hum. Vaccin. Immunother. 10 (7), 2083-2088.

Pang, W.W., Price, E.A., Sahoo, D., Beerman, I., Maloney, W.J., Rossi, D.J., Schrier, S.L., Weissman, I.L., 2011. Human bone marrow hematopoietic stem cells are increased in frequency and myeloid-biased with age. Proc. Natl. Acad. Sci. U. S. A. 108 (50), 20012-20017.

Parmigiani, A., Alcaide, M.L., Freguja, R., Pallikkuth, S., Frasca, D., Fischl, M.A., Pahwa, S., 2013. Impaired antibody response to influenza vaccine in HIV-infected and uninfected aging women is associated with immune activation and inflammation. PLoS One 8, e79816.

Pawelec, G., 2014a. Immunosenenescence: role of cytomegalovirus. Exp. Gerontol. $54,1-5$.

Pawelec, G., 2014b. T-cell immunity in the aging human. Haematologica 99 (5), $795-797$.

Perez-Andres, M., Paiva, B., Nieto, W.G., Caraux, A., Schmitz, A., Almeida, J., Vogt, R.F. Jr., Marti, G.E., Rawstron, A.C., Van Zelm, M.C., Van Dongen, J.J., Johnsen, H.E., Klein, B., Orfao, A., 2010. Primary Health Care Group of Salamanca for the Study of MBL. Human peripheral blood B-cell compartments: a crossroad in B-cell traffic. Cytometry B Clin. Cytom. 78 (Suppl. 1), S47-S60.

Pillai, S., Cariappa, A., 2009. The follicular versusmarginal zone B lymphocyte cell fate decision. Nat. Rev. Immunol. 9, 767-777.

Pinti, M., Appay, V., Campisi, J., Frasca, D., Fülöp, T., Sauce, D., Larbi, A., Weinberger B., Cossarizza, A., 2016. Aging of the immune system: focus on inflammation and vaccination. Eur. J. Immunol. 46 (10), 2286-2301. 
Pritz, T., Lair, J., Ban, M., Keller, M., Weinberger, B., Krismer, M., Grubeck-Loebenstein, B., 2015. Plasma cell numbers decrease in bone marrow of old patients. Eur. J. Immunol. 45 (3), 738-746.

Pronk, C.J., Veiby, O.P., Bryder, D., Jacobsen, S.E., 2011. Tumor necrosis factor restricts hematopoietic stem cell activity in mice: involvement of two distinct receptors. J. Exp. Med. 208 (8), 1563-1570.

Puzianowska-Kuźnicka, M., Owczarz, M., Wieczorowska-Tobis, K., Nadrowski, P., Chudek, J., Slusarczyk, P., Skalska, A., Jonas, M., Franek, E., Mossakowska, M., 2016. Interleukin-6 and C-reactive protein successful aging, and mortality: the Pol Senior study. Immun. Ageing 3, 13-21.

Ratliff, M., Alter, S., Frasca, D., Blomberg, B.B., Riley, R.L., 2013. In senescence, age-associated B cells secrete TNF-alpha and inhibit survival of B-cell precursors. Aging Cell 12, 303-311.

Reber, A.J., Chirkova, T., Kim, J.H., Cao, W., Biber, R., Shay, D.K., Sambhara, S., 2012. Immunosenescence and challenges of vaccination against influenza in the aging population. Aging Dis. 3 (1), 68-90.

Riley, R.L., 2013. Impaired B lymphopoiesis in old age: a role for inflammatory B cells? Immunol. Res. 57 (1-3), 361-369.

Rosser, E.C., Mauri, C., 2015. Regulatory B cells: origin, phenotype, and function. Immunity 42 (4), 607-612.

Rossi, D.J., Bryder, D., Zahn, J.M., Ahlenius, H., Sonu, R., Wagers, A.J., Weissman, I.L., 2005. Cell intrinsic alterations underlie hematopoietic stem cell aging. Proc. Natl. Acad. Sci. U. S. A. 102 (26), 9194-9199.

Rubtsova, K., Rubtsov, A.V., Cancro, M.P., Marrack, P., 2015. Age-associated B cells: a T-bet-dependent effector with roles in protective and pathogenic immunity. J. Immunol. 195 (5), 1933-1937.

Sagaert, X., De Wolf-Peeters, C., 2003. Classification of B-cells according to their differentiation status: their micro-anatomical localization and their developmental lineage. Immunol. Lett. 90, 179-186.

Salvioli, S., Monti, D., Lanzarini, C., Conte, M., Pirazzini, C., Bacalini, M.G., Garagnani, P., Giuliani, C., Fontanesi, E., Ostan, R., Bucci, L., Sevini, F., Yani, S.L., Barbieri, A., Lomartire, L., Borelli, V., Vianello, D., Bellavista, E., Martucci, M., Cevenini, E., Pini, E., Scurti, M., Biondi, F., Santoro, A., Capri, M., Franceschi, C., 2013. Immune system, cell senescence, aging and longevity-inflamm-aging reappraised. Curr. Pharm. Des. 19 (9), 1675-1679.

Sanz, I., Wei, C., Lee, F.E., Anolik, J., 2008. Phenotypic and functional heterogeneity of human memory B cells. Semin. Immunol. 20 (1), 67-82.

Schutyser, E., Struyf, S., Van Damme, J., 2003. The CC chemokine CCL20 and its receptor CCR6. Cytokine Growth Factor Rev. 14 (5), 409-426.

Shi, Y., Yamazaki, T., Okubo, Y., Uehara, Y., Sugane, K., Agematsu, K., 2005. Regulation of aged humoral immune defense against pneumococcal bacteria by IgM memory B cell. J. Immunol. 175, 3262-3267.

Singh, T., Newman, A.B., 2011. Inflammatory markers in population studies of aging. Ageing Res. Rev. 10 (3), 319-329.

Son, N.H., Joyce, B., Hieatt, A., Chrest, F.J., Yanovski, J., Weng, N.P., 2003. Stable telomere length and telomerase expression from naïve to memory B-lymphocyte differentiation. Mech. Ageing Dev. 124 (4), 427-432.
Stavnezer, J., Guikema, J.E., Schrader, C.E., 2008. Mechanism and regulation of class switch recombination. Annu. Rev. Immunol. 26, 261-292.

Stein, J.V., Nombela-Arrieta, C., 2005. Chemokine control of lymphocyte trafficking: a general overview. Immunology 116, 1-12

Strindhall, J., Nilsson, B.O., Löfgren, S., Ernerudh, J., Pawelec, G., Johansson, B., Wikby, A., 2007. No Immune Risk Profile among individuals who reach 100 years of age: findings from the Swedish NONA immune longitudinal study. Exp. Gerontol. 42 (8), 753-761.

Ueda, Y., Yang, K., Foster, S.J., Kondo, M., Kelsoe, G., 2004. Inflammation controls B lymphopoiesis by regulating chemokine CXCL12 expression. J. Exp. Med. 199 (1), 47-58.

VanDyk, L., Meek, K., 1992. Assembly of IgH CDR3: mechanism, regulation, and influence on antibody diversity. Int. Rev. Immunol. 8, 123-133.

Vasto, S., Candore, G., Balistreri, C.R., Caruso, M., Colonna-Romano, G., Grimaldi, M.P., Listì, F., Nuzzo, D., Lio, D., Caruso, C., 2007. Inflammatory networks in ageing, age-related diseases and longevity. Mech. Ageing Dev. 128 (1), 83-91.

Vazquez, M.I., Catalan-Dibene, J., Zlotnik, A., 2015. B cells responses and cytokine production are regulated by their immune microenvironment. Cytokine 74 (2), 318-326.

Wang, C., Liu, Y., Jackson, K.J.L., Roskin, K.M., Pham, T.D., Laserson, J., Marshall, E.L., Seo, K., Lee, J.Y., Furmar, D., Koller, D., Dekker, C.L., Davis, M.M., Fire, A.Z., Boy, S.D., 2014. Effects of aging, CMV infection, and EBV infection on human B cell repertoires. J. Immunol. 192 (2), 603-611.

Wei, C., Anolik, J., Cappione, A., Zheng, B., Pugh-Bernard, A., Brooks, J., Lee, E.H., Milner, E.C., Sanz, I., 2007. A new population of cells lacking expression of CD27 represents a notable component of the B cell memory compartment in systemic lupus erythematosus. J. Immunol. 178 (10), 6624-6633.

Weksler, M.E., Szabo, P., 2000. The effect of age on the B-cell repertoire. J. Clin. Immunol. 20, 240-249.

Welsh-Bacic, D., Lindenmeyer, M., Cohen, C.D., Draganovici, D., Mandelbaum, J., Edenhofer, I., Ziegler, U., Regele, H., Wüthrich, R.P., Segerer, S., 2010. Expression of the chemokine receptor CCR6 in human renal inflammation. Nephrol. Dial. Transplant. 26 (4), 1211-1220.

Wikby, A., Ferguson, F., Forsey, R., Thompson, J., Strindhall, J., Löfgren, S., Nilsson, B.O., Ernerudh, J., Pawelec, G., Johansson, B., 2005. An immune risk phenotype, cognitive impairment, and survival in very late life: impact of allostatic load in Swedish octogenarian and nonagenarian humans. J. Gerontol. A Biol. Sci. Med. Sci. 60 (5), 556-565.

William, J., Euler, C., Christensen, S., Shlomchik, M.J., 2002. Evolution of autoantibody responses via somatic hypermutation outside of germinal centers. Science 297 (5589), 2066-2070.

Zheng, B., Han, S., Takahashi, Y., Kelsoe, G., 1997. Immunosenescence and germinal center reaction. Immunol. Rev. 160, 63-77. 